\title{
Impact of exposures to persistent endocrine disrupting compounds on the sperm methylome in regions associated with neurodevelopmental disorders
}

Angela G. Maggio ${ }^{1}$, Henry T. Shu ${ }^{1,2}$, Benjamin I. Laufer ${ }^{3}$, Hyeyeon Hwang ${ }^{3}$, Chongfeng Bi ${ }^{1}$, Yinglei Lai ${ }^{4}$, Janine M. LaSalle ${ }^{3}$, and Valerie W. Hu ${ }^{1}$

${ }^{1}$ Dept. of Biochemistry and Molecular Medicine; The George Washington University School of Medicine and Health Sciences; Washington, DC 20037 USA

${ }^{2}$ The Johns Hopkins University, School of Medicine; 733 N Broadway St, Baltimore, MD 21205 USA

${ }^{3}$ Medical Microbiology and Immunology, Genome Center, MIND Institute, Perinatal Origins of Disparities Center, and Environmental Health Sciences Center, UC Davis School of Medicine, Davis, CA 95616 USA

${ }^{4}$ Dept. of Statistics, The George Washington University, Washington, DC 20052 USA

Address correspondence to: Valerie Hu, Department of Biochemistry and Molecular Medicine, The George Washington University School of Medicine and Health Sciences, 2300 Eye St., NW, Washington, DC 20037, USA. Telephone: (202) 994-8431. Email: valhu@gwu.edu

The authors declare they have no actual or potential competing financial interests.

Keywords: DNA methylation, sperm, Faroe Islands, endocrine disruptors, autism 


\begin{abstract}
Background: Although autism spectrum disorder (ASD) is among the most heritable of neurodevelopmental disorders, the rapidly rising prevalence of ASD suggests that environmental factors may interact with genetic risk for ASD. Environmental factors may impact both gene expression and phenotypes in ASD through epigenetic modifications that, in turn, could lead to intergenerational effects influencing risk for ASDs. Endocrine disrupting compounds (EDCs), such as the long-lived organochlorines, are of particular interest with respect to risk for autism because of their ability to interfere with sex hormones that have been implicated in the regulation of $R O R A$, a dysregulated gene in ASD that is a master regulator of many other ASD risk genes. Objectives: The specific aims of this study are to: 1) investigate whether high versus low exposures to the persistent organochlorine 1,1-dichloro-2,2-bis(p-chlorophenyl)ethylene (DDE) are associated with differentially methylated regions (DMRs) in sperm from a Faroese cohort whose natural diet of pilot whale meat and blubber exposes them to higher than average levels of organic pollutants; 2) determine if genes associated with DDE DMRs are enriched for ASD risk genes; 3) identify pathways and functions over-represented among genes associated with DMRs. Methods: Whole genome bisulfite sequencing (WGBS) was used to identify genome-wide DMRs in sperm from individuals divided by high and low exposure levels. Gene ontology and pathway analyses were used to determine enrichment in functional relationships to ASD. Results: Genes in DMRs not only could discriminate between high and low exposures to DDE, but also were enriched in autism risk genes. Gene ontology and pathway analyses of these genes show significant enrichment for neurodevelopmental processes frequently impacted by ASD. Conclusion: Results of this study show that elevated exposure to certain organochlorines is associated with genome-wide DNA methylation patterns in sperm affecting genes involved in neurological functions and developmental disorders, including ASD.
\end{abstract}


medRxiv preprint doi: https://doi.org/10.1101/2021.02.21.21252162; this version posted February 23, 2021. The copyright holder for this preprint

(which was not certified by peer review) is the author/funder, who has granted medRxiv a license to display the preprint in perpetuity.

All rights reserved. No reuse allowed without permission.

\section{Introduction}

Autism spectrum disorder (ASD) is a highly complex neurodevelopmental disorder characterized by deficits in social communication, repetitive behaviors, and restricted interests (American Psychiatric Association. Task Force on DSM-5, 2013). In a span of only 12 years from 2004 to 2016, the United States' Center for Disease Control and Prevention reported an increase in prevalence of ASD from roughly 1 in 125 children to 1 in 54, with a male to female sex bias of 4.3 to 1 (Maenner et al., 2020). While increased awareness of the disorder and expansion of the diagnosis to include the moderate and milder forms of ASD (such as pervasive developmental disorder-not otherwise specified and Asperger syndrome) has been suggested to account for the increase in prevalence, epidemiological studies suggest that there may be environmental contributions to ASD as well (Nevison, 2014). Similarly, although ASD exhibits a strong genetic component as revealed by concordance rates in studies on affected monozygotic versus dizygotic twins (Hallmayer et al., 2011; Tordjman et al., 2014), the incomplete penetrance of ASD even in monozygotic twins also suggests a role for gene by environment $(\mathrm{G} \times \mathrm{E})$ interactions which are often mediated through epigenetic mechanisms.

Early evidence for the involvement of epigenetics in neurodevelopmental disorders comes from studies on syndromic forms of ASD (e.g., Fragile X, Angelman's, Prader-Willi, and Rett syndromes) in which the etiologically relevant genes are either aberrantly methylated/imprinted or are involved in the recognition of methylated DNA sequences (Grafodatskaya, Chung, Szatmari, \& Weksberg, 2010; Rangasamy, D'Mello, \& Narayanan, 2013). In 2010, we demonstrated for the first time genome-wide DNA methylation differences associated with idiopathic autism in lymphoblastoid cell lines (LCLs) from monozygotic twins and sib pairs discordant for diagnosis of autism (Nguyen, Rauch, Pfeifer, \& $\mathrm{Hu}, 2010)$. 
Importantly, by integrating these large-scale methylation analyses with genome-wide transcriptome analyses of the same cohort, we showed that the majority of the methylation differences were inversely associated with differences in gene expression (Hu, Frank, Heine, Lee, \& Quackenbush, 2006; Hu et al., 2009). Moreover, two of the validated hypermethylated genes, BCL2 and RORA, were also found to be reduced in brain tissues from individuals with ASD (Nguyen et al., 2010), thus linking these molecular changes observed in blood-derived cells to autism brain pathology. We further showed that $R O R A$ could be regulated in opposite directions by male and female sex hormones, with male hormones suppressing expression (Sarachana, $\mathrm{Xu}, \mathrm{Wu}, \& \mathrm{Hu}, 2011)$. In addition, we demonstrated that over 2000 genes were putative transcriptional targets of this nuclear hormone receptor, including hundreds of autism risk genes (Sarachana $\& \mathrm{Hu}, 2013$ ). These findings led us to postulate that this hormonal dependence of RORA expression might contribute to the observed sex bias in ASD that has been hypothesized to be related to elevated fetal testosterone or steroidogenic activity (Baron-Cohen et al., 2014; Simon Baron-Cohen, Knickmeyer, \& Belmonte, 2005). Moreover, we postulated that endocrine disrupting compounds (EDCs) that can mimic or interfere with normal hormonal signaling and metabolism might perturb the expression and function of this critical candidate gene for ASD, thereby increasing risk for autism (Hu, 2012).

Indeed, environmental exposures to EDCs have been linked with various diseases including neurodevelopmental disorders (Braun, 2017; Gore, Martien, Gagnidze, \& Pfaff, 2014; Rivollier, Krebs, \& Kebir, 2019; Schug, Blawas, Gray, Heindel, \& Lawler, 2015). Both experimental and epidemiological studies have reported harmful effects of exposures to both short- and long-lived EDCs, such as bisphenol A (BPA) and phthalates, and persistent organic pollutants (POPs) like polychlorinated biphenyl (PCB) and polybrominated diphenyl ether 
(PBDE) compounds, on neurodevelopment. Rodent studies have shown associations between EDC exposure and disruption of social hormones, social recognition, locomotion, and excitatoryinhibitory synapse pathways (Gogolla et al., 2009; Lichtensteiger et al., 2015; Wolstenholme, Goldsby, \& Rissman, 2013). Exposure to 3,3'-dichlorobiphenyl exerted effects on axonal and dendritic growth in primary rat neurons (Sethi et al., 2017). Epidemiological studies further show that prenatal human exposures to EDCs, specifically DDE and PCBs, has been linked to alterations in hormone levels in offspring with potential for lasting and widespread signaling disruption (Braun, 2017; Eskenazi et al., 2017).

With respect to mechanisms of action, many studies have investigated epigenetics as a potential mediator of EDC-induced changes in phenotype and disease state. For example, Manikkam et al. showed that certain plastics-derived EDCs induced transgenerational inheritance of obesity, reproductive disease and epimutations in sperm (Manikkam, GuerreroBosagna, Tracey, Haque, \& Skinner, 2012). More recently, McBirney et al. reported that exposure of pregnant rats during gestation to the herbicide atrazine increased the frequency of testis disease and mammary tumors as well as induced changes in body weight and onset of puberty in the F2 and F3 offspring (McBirney et al., 2017). Additionally, they reported DNA methylation changes in sperm, which were detected in offspring in each generation (McBirney et al., 2017). Regarding EDC involvement in autism, Dunaway et al. demonstrated that treatment of a neuronal cell model with PCB 95 was associated with significant global DNA hypomethylation of autism candidate genes with a direct impact on gene expression (Dunaway et al., 2016). In the same study, hypomethylation was also observed in brain tissues from individuals with Dup15q syndrome (a condition frequently associated with ASD) which had been previously associated with exposure to PCB 95 (Mitchell et al., 2012). The role of epigenetics as an underlying 
mechanism for EDC-induced neurodevelopmental disorders and ASD is further discussed in a number of recent reviews (Bakulski, Singer, \& Fallin, 2014; Lasalle, 2013; Moosa, Shu, Sarachana, \& Hu, 2018; Tran \& Miyake, 2017).

In addition to having an impact on neurodevelopment, EDCs have also been implicated in many other diseases or human conditions, such as cancer, diabetes, obesity, metabolic disorders, and infertility (De Coster \& Van Larebeke, 2012). With respect to infertility, human exposures to a variety of organochlorines have been shown to affect chromatin integrity (Rignell-Hydbom et al., 2005) and sex chromosome aneuploidy in sperm (McAuliffe, Williams, Korrick, Altshul, \& Perry, 2012). EDC-associated sex chromosome aneuploidy in sperm was further confirmed in an additional study involving a cohort of men in the Faroe Islands who have higher than average exposures to POPs based on their diet which is rich in pilot whale meat and blubber (Perry et al., 2016). These chromosomal changes in sperm suggested that EDCs may also induce epigenetic changes in sperm DNA.

In recent years, the sperm methylome (i.e., genome-wide DNA methylation pattern) has come under increasing scrutiny as a reservoir of epigenetic changes that may have an impact on a wide variety of human disorders, from infertility to neurodevelopmental and psychiatric disorders (Wu, Hauser, Krawetz, \& Pilsner, 2015). In particular, DNA methylation changes in sperm have been reported as a function of advanced paternal age, in both mice and men (Jenkins, Aston, Pflueger, Cairns, \& Carrell, 2014; Milekic et al., 2014). Notably, the changes have included genes that overlap with those reportedly associated with autism, schizophrenia, and bipolar disorder. Since advanced paternal age has also been associated with risk for autism (Quinlan, McVeigh, Driver, Govind, \& Karpati, 2015; Reichenberg et al., 2006; Vierck \& Silverman, 2014), Feinberg et al. recently investigated DNA methylation differences in sperm 
medRxiv preprint doi: https://doi.org/10.1101/2021.02.21.21252162; this version posted February 23, 2021. The copyright holder for this preprint

(which was not certified by peer review) is the author/funder, who has granted medRxiv a license to display the preprint in perpetuity.

All rights reserved. No reuse allowed without permission.

from fathers with a child with ASD and from fathers of neurotypical children (Feinberg et al., 2015). They identified 193 DMRs in paternal sperm of ASD fathers, many of which were in the proximity of genes involved in developmental processes. A more recent study on the sperm methylome of fathers that have children with or without ASD further shows the potential for development of a biomarker screen for ASD based on DMRs (Garrido et al., 2021). These studies thus establish a link between DNA methylation changes in sperm and possible risk for ASD. However, it does not address potential environmental contributors to such methylation changes in sperm of the fathers with children affected by ASD.

The primary objectives of this study are to: 1) determine if high versus low exposures to the persistent organochlorine 1,1-dichloro-2,2-bis(p-chlorophenyl)ethylene (DDE) are associated with differentially methylated regions (DMRs) in sperm from a Faroese cohort; 2) determine if genes associated with DDE DMRs are enriched for ASD risk genes; 3) identify pathways and functions among genes associated with DMRs.

\section{Materials and methods}

\section{Semen samples and demographics of donors}

Raw ejaculate (i.e., semen) from 52 men in a general population cohort of the Faroe Islands (Denmark) was kindly provided by Dr. Pál Weihe, Director of the Department of Occupational Medicine and Public Health of the Faroese Hospital System in Tórshavn, Faroe Islands. Inhabitants of the Faroe Islands are considered genetic isolates and therefore are expected to have similar genetic background and polymorphisms that would otherwise be considered major confounding variables in genomics studies. Samples were collected throughout 2007 and 2008 and de-identified by the Faroese Hospital System. Information related to height, weight, age, smoking status, length of abstinence, sample collection date, serum concentrations 
of the four most prevalent PCB congeners, (PCB 118, PCB 138, PCB 153, PCB 180) and DDE, the major breakdown product of the insecticide DDT (dichloro-diphenyl-trichloroethane) were recorded for each sample as part of the Faroese General Population research cohort (which was part of the parent study approved by the local Science Ethics Committee for the Faroe Islands). The de-identified semen samples were made available for this study through a Data Processor Agreement between Dr. Pál Weihe at the Faroese Hospital System and Dr. Valerie Hu at The George Washington University, together with the serum levels of the organochlorines that had been determined for each donor as previously described (Grandjean et al., 2001). A summary of demographic information and serum concentrations of EDCs for the cohort used in this study is provided in Supplemental Table 1. Regression analyses of the potential covariates were performed using statistical packages in Excel. These analyses showed that while there were significant correlations between the concentrations of DDE with those of DDT and the sum of the four most prevalent PCB congeners (Supplemental Figure 1), there were no correlations between DDE levels and body mass index (BMI), smoking status, or any of the sperm parameters, including sperm concentration and mobility (Supplemental Figures 2 and 3). Faroese semen samples with a minimum sperm count of $20 \times 10^{6}$ per ml were divided by Dr. Melissa Perry (GWU) into three exposure groups based on the recorded levels of DDE in serum, and 26 samples each from the first (lowest exposure) and third (highest exposure) tertiles were provided for this methylation study. It should be noted that, once the 52 semen samples were received, they were processed through bisulfite sequencing analyses without knowledge of the exposure tertiles to which they were assigned.

\section{Sperm isolation and DNA extraction methods}


Sperm was isolated from semen (which contains various cell types) using a published discontinuous gradient protocol (Wu, de Gannes, Luchetti, \& Richard Pilsner, 2015). Briefly, $100 \mu \mathrm{l}$ of semen was washed with 2 mL Quinn's Sperm Washing Medium (Origio, Trumbull, $\mathrm{CT}$ ), and cells were pelleted at $600 \mathrm{~g}$ for 5 minutes at $4^{\circ} \mathrm{C}$. The pelleted cells were resuspended in $0.5 \mathrm{ml}$ Quinn's solution and counted in a hemocytometer to determine the initial number of sperm and somatic cells in the semen sample. Next, a discontinuous gradient of PureCeption solution (Origio) diluted with Quinn's was formed in a $15 \mathrm{ml}$ conical tube with $1.5 \mathrm{ml}$ of $40 \%$ PureCeption over $1.5 \mathrm{ml}$ of $90 \%$ PureCeption. The washed cells were layered on top of the gradient before centrifugation at $300 \mathrm{~g}$ for 20 minutes at room temperature. The pellet was transferred to a new $15 \mathrm{ml}$ tube and resuspended in $3 \mathrm{ml}$ Quinn's Washing solution. The cells were pelleted at $600 \mathrm{~g}$ for 5 minutes, and then resuspended in $500 \mu$ Q Quinn's after removal of the supernatant. Cells were recounted to determine total number of sperm and somatic cell contamination (which never exceeded 1\%) before centrifugation at $4000 \mathrm{~g}$ for 1 minute.

DNA was isolated from the purified sperm cells using a Qiagen AllPrep DNA/RNA mini kit following the manufacturer's protocol. Sperm pellets were first lysed in $450 \mu \mathrm{l}$ RT buffer with $50 \mu$ added tris(2-carboxyethyl)phosphine solution (TCEP, a bond-breaker) by vortexing with 0.1 gm RNase/DNase-free stainless steel microbeads for 5 min at RT in a Disruptor Genie (Scientific Industries, Bohemia, NY). Lysates were immediately stored at $-80^{\circ} \mathrm{C}$ until DNA extraction which was usually completed the next day using the standard protocol.

\section{Whole Genome Bisulfite Sequencing (WGBS)}

Samples for WGBS were divided into two batches, a discovery set of 32 samples and a validation set of 20 samples. The samples were sent to Admera Health (South Plainfield, NJ), a CLIA-certified laboratory, for WGBS analyses. The directional Illumina TruSeq DNA 
Methylation library kit was used for sample preparation. WGBS was then performed on an Illumina HiSeq X sequencer resulting in 150 bp PE reads achieving roughly $4 x$ coverage genome wide per sample. Raw FASTQ files were received from Admera Health for further analyses. As mentioned previously, all samples were processed blindly without the processors' knowledge of tertile level from sperm isolation through the WGBS analyses to minimize handling bias.

\section{WGBS bioinformatics pipeline}

We utilized a bioinformatics pipeline comprised of CpG_Me for alignment and DMRichR for differential methylation determination as published on github (https://github.com/ben-laufer). $\mathrm{CpG}$ _Me builds on previously published bioinformatic tools and pipelines (Krueger \& Andrews, 2011; Laufer, Hwang, Vogel Ciernia, Mordaunt, \& LaSalle, 2019). The DMRichR workflow similarly builds on previously established bioinformatic packages such as dmrseq and bsseq (Hansen, Langmead, \& Irizarry, 2012; Korthauer, Chakraborty, Benjamini, \& Irizarry, 2019; Laufer et al., 2019). All WGBS data was analyzed on The George Washington University's high-performance cluster, Colonial One. First, raw read files (FASTA) were trimmed and quality checked with Trim-Galore and FASTQC software. Forward reads were trimmed by $8 \mathrm{bp}$ on the 3 '- and 5'-ends. Reverse reads were trimmed $8 \mathrm{bp}$ on the, 3 '-ends and $20 \mathrm{bp}$ on the 5 '-ends in order to remove methylation bias often seen at the ends of reads. M-Bias plots from FASTQC analyses were examined to determine if trimming was sufficient. Trim Galore was also used to filter out bases with Phred scores lower than 20 that would indicate a 1 in 100 probability of an incorrect base call. Reads were then aligned to a reference human genome (hg38) using Bismark, a three-letter aligner. Methylation calls are differentiated among $\mathrm{CpG}, \mathrm{CHG}$, and $\mathrm{CHH}$ contexts (Krueger \& Andrews, 2011), but only the CpG sites were considered in this study. Approximately $74 \%$ of bisulfite reads aligned to a 
bisulfite-converted reference human genome allowing for the assay of 10.08 million CpG sites.

All raw and processed data from the WGBS analyses have been deposited into the NBCI's Gene Expression Omnibus (GEO) repository (GEO Accession number GSE165915).

\section{Identification of differentially methylated regions (DMRs)}

DMRs were identified using dmrseq and bsseq Bioconductor packages in the wrapped pipeline of DMRichR. Default parameters for the DMRichR executable script were used which included coverage set to $1 \mathrm{x}$, per Group set to $100 \%$, minCpGs set to 5, and maxPerms set to 10 . Covariables adjusted for in DMR analysis included BMI, age, days in storage, batch effects of processor and date of processing, percent motile sperm, and smoking status. With DMRichR, DMRs were annotated for genomic and CG context. Annotation resources within DMRichR include the annotatr and rGREAT (Genomic Regions Enrichment of Annotations Tool) open source packages in Bioconductor. Annotatr (Cavalcante \& Sartor, 2017) was used to visualize and compare annotated genomic sites/regions (e.g., promoters, 5'UTRs, exons, introns) that were identified within the discovery and validation sets, while rGREAT (Gu, 2014) was used for mapping genes to the sites. The mapped genes were then utilized for pathway and functional analyses using Ingenuity Pathway Analysis software (Qiagen, Germantown, MD) as described below.

\section{Gene ontology and network prediction analysis}

Gene ontology analysis of the DMRs assigned to genes was accomplished using two different programs; GofuncR (Grote, 2020), which was modified for use with DMRichR, and the open-access STRING Version 11.0 (Search Tool for the Retrieval of Interacting Genes/Proteins) (Szklarczyk et al., 2019). GofuncR maps a DMR to a gene if it is between $5 \mathrm{~kb}$ upstream and 1 $\mathrm{kb}$ downstream of the gene body and also uses information from the background regions. A 
custom meta p-value analysis was performed using the sum of logs of the p-values of GO terms to integrate the data from the discovery and validation sets, and then terms with a meta p-value $<$ 0.05 were slimmed using REVIGO (Supek, Bošnjak, Škunca, \& Šmuc, 2011) to reduce redundancy among the most significant GO terms. Ingenuity Pathway Analysis (IPA) Version 01-13 (Qiagen, Germantown, MD) was used to discover pathways and functions enriched among the DMR-associated genes based on Fisher Exact p-values of $\leq 0.05$, using the curated genes in IPA's Knowledgebase as the reference gene set. The overall workflow for this study is summarized in Figure 1.

\section{Class prediction analysis of WGBS data using machine-learning approaches}

In order to select reliable predictors of DDE exposure levels for further validation by pyrosequencing, random forest (RF) and linear support vector machine (SVM) models were used to create binary classifiers that identify the exposure class (either 'First' or 'Third' tertile) of a given sample. A total of 261 DMRs from the analysis of all 52 samples, without ComBat batch correction, were utilized as predictors for the models. The samples were split according to sequencing batch, where the 32 samples from the first batch were used as a training set, and the 20 samples from the second batch were used as a testing set. The training set consisted of 16 samples in the 'Third' tertile and 16 matched controls labeled as the 'First' tertile. Similarly, the testing set consisted of 10 samples in each of these two tertile groups. Then, the machine learning model, either RF or SVM, was built with 5-fold cross-validation on the training set and used to predict the DDE exposure 'Tertile' class in the testing set.

To identify the most predictive DMRs for DDE exposure, we used two wrapper feature selection algorithms from the sigFeature Bioconductor package and the Boruta $\mathrm{R}$ package. Among the three types of feature selection methods (filter, embedded, and wrapper), we chose 
medRxiv preprint doi: https://doi.org/10.1101/2021.02.21.21252162; this version posted February 23, 2021. The copyright holder for this preprint

(which was not certified by peer review) is the author/funder, who has granted medRxiv a license to display the preprint in perpetuity.

All rights reserved. No reuse allowed without permission.

the wrapper method as it usually provides the most relevant feature set for a specific model.

Wrapper methods rank features by repeatedly generating a subset of features from the full set of features and training a particular type of model using the generated subset.

There are many variable selection methods for the RF algorithm, but the Boruta algorithm was shown to be the most relevant, as it identifies all relevant variables, including variables that contain redundant information. In genomics studies, the inclusion of correlated and thus redundant variables may be important for model performance and the consistency of results(Degenhardt, Seifert, \& Szymczak, 2019). The Boruta algorithm in the Boruta package applies the RF algorithm from the randomForest R package (Kursa \& Rudnicki, 2010).

Of the variable selection methods that use the SVM algorithm, we decided to use the SVM recursive feature elimination (SVM-RFE) algorithm and t-statistic from the sigFeature package. SVM-RFE, one of the most effective feature selection methods, uses a greedy algorithm to find the best subset of features for binary classification tasks but does not consider differentially significant features between classes. The sigFeature package addresses this limitation by using the t-statistic to also find differentially significant features (Das, Roychowdhury, Das, Roychoudhury, \& Tripathy, 2020).

\section{Pyrosequencing analyses}

Pyrosequencing analyses of selected DMRs were performed in the Weksberg laboratory at The SickKids Research Institute of The Hospital for Sick Children; Toronto, Ontario, Canada. These DMRs included specific regions for CSMD1, NRXN2, RBFOX1, MIRLET7BHG, PTPRN2, SNORD115-30, and SNORD115-37 that were identified by the WGBS analyses. Primers for each of the regions that typically included multiple methylation sites as well as the PCR conditions for the pyrosequencing analyses are provided in Supplemental File 1. The 
medRxiv preprint doi: https://doi.org/10.1101/2021.02.21.21252162; this version posted February 23, 2021. The copyright holder for this preprint (which was not certified by peer review) is the author/funder, who has granted medRxiv a license to display the preprint in perpetuity.

All rights reserved. No reuse allowed without permission.

resulting pyrosequencing data were returned to us for further analyses of the methylation profiles of each region as a function of DDE serum concentration $(\mu \mathrm{g} / \mathrm{gm}$ lipid) for each sample.

\section{Hypergeometric distribution analyses}

Hypergeometric distribution analyses were employed to identify the significance of overlap between DMR-associated genes and autism risk genes from the SFARI Gene database (Abrahams et al., 2013). First, the overlapping genes were identified using a Venn diagram software program called Venny 2.1.0 https://bioinfogp.cng.csic.es/tools/venny/ (Oliveros, 2007). Significant overlap between the DMR-associated genes and SFARI genes was determined by hypergeometric distribution analyses using the CASIO Keisan Online Calculator $<$ http://keisan.casio.com/exec/system/1180573201>, with significance determined by an upper cumulative Q-value of $\leq 0.05$. These two programs were also used to identify significant overlap of DMR-associated genes from this study and those from other studies.

\section{Results}

\section{DMRs associated with high and low exposures to DDE}

WGBS analyses of the initial 32 samples (discovery set) with correction for all covariates revealed a total of 894 differentially methylated regions (DMRs, permutation $\mathrm{p} \leq 0.05$ ) between the first and third DDE exposure tertiles, while subsequent analyses of the validation set of 20 samples resulted in a total of 865 DMRs (Figure 2, DMRs in Supplemental Tables 2 and 3). The overall distribution profiles of annotated gene and $\mathrm{CpG}$ regions were similar for both analyses (Suppl. Figure 4). Analysis of larger blocks of sequence for differential methylation revealed a single region that reached genome-wide significance after multiple testing correction $(q<0.022)$ when all 52 samples were combined (Figure 3). This block covered a 40,618 bp 
medRxiv preprint doi: https://doi.org/10.1101/2021.02.21.21252162; this version posted February 23, 2021. The copyright holder for this preprint (which was not certified by peer review) is the author/funder, who has granted medRxiv a license to display the preprint in perpetuity.

All rights reserved. No reuse allowed without permission.

region of the SNORD115 locus that is maternally imprinted, meaning expressed exclusively from the paternal allele. The validation data set shows nominal significance for increased methylation across this locus with a width of $63,606 \mathrm{bp}(\mathrm{p}<0.011)$.

\section{Sperm DMRs associated with neurodevelopmental processes and ASD-risk genes}

Gene ontology analyses of the genes within the DMRs in both discovery and validation samples were performed using two different gene mapping and ontology approaches. GOfuncR analysis provides an overview of the top biological processes, cellular components, and molecular functions associated with the DMR-associated genes from both discovery and validation sets (Figure 4), while STRING analysis of these genes not only replicates some of the GO terms from the GOfuncR analysis but also reveals significant over-representation of a number of processes involved in nervous system development and function that are shared by both datasets (Table 1). Notably, these shared processes include nervous system development, generation of neurons, neurogenesis, neuron differentiation, and synapse organization. The enrichment in neuronal processes was further confirmed by pathway and functional analyses of the DMR-associated genes using IPA. CREB signaling in neurons, the endocannabinoid developing neuron pathway, netrin signaling, calcium signaling, GABA signaling, and axon guidance signaling are among the canonical pathways significantly enriched in both data sets

(Table 2), while recognition of neurons, outgrowth of neurites, and neurotransmission are shared functions over-represented among the DMR-associated genes (Table 3).

To further investigate the relevance of these DMR-associated genes to ASD, we performed hypergeometric distribution analyses to determine enrichment in autism risk genes from the SFARI Gene database. Figure 5 shows the overlap between DMR-associated genes from the discovery and validation analyses as well as the overlap between these DMR associated 
genes and the SFARI genes. The upper cumulative Q-values for enrichment in SFARI genes were $2.5 \times 10^{-7}$ and $1.1 \times 10^{-5}$ for the discovery and validation sets, respectively. Of the 138 overlapping DMR-associated genes between the discovery and validation sets, 14 are included in the SFARI Gene database. Notably, all of these genes are involved in development.

\section{Class prediction analysis using a machine-learning approach}

An attempt was made to identify DMRs that could reliably assign samples to the high or low exposure levels. Both random forest and linear support vector machine models were independently applied to the entire set of 261 DMRs obtained using all 52 samples (Supplemental Table 4). The discovery set of samples was used for training the classifier, and the validation set was used for testing the classifier. Table 4 shows 15 of the top predictors resulting from these two classification approaches.

\section{Pyrosequencing analyses of several DMR-associated ASD risk genes}

Several DMRs were selected for pyrosequencing validation. These included the regions harboring known autism risk genes, $C S M D 1, N R X N 2$, and $R B F O X 1$, all of which were found to be differentially methylated in both discovery and validation analyses. In addition, we included PTPRN2 which, like $N R X N 2$, was found to be differentially methylated in cord blood from the Faroese population as a function of level of DDE exposure (Leung et al., 2018). Also selected for pyrosequencing were MIRLET7HBG which was implicated by the classifier analyses and two SNORDs (SNORD115-30 and SNORD115-37) which are located in an imprinted region identified as differentially methylated in this study as well as in a previous study on paternal sperm from men with an autistic child (Feinberg et al., 2015). Figure 6 shows the correlation curves for methyation level versus serum DDE exposure level for CSMD1, NRXN2, and RBFOX1. All of these genes showed a modest but statistically significant inverse correlation 
medRxiv preprint doi: https://doi.org/10.1101/2021.02.21.21252162; this version posted February 23, 2021. The copyright holder for this preprint

(which was not certified by peer review) is the author/funder, who has granted medRxiv a license to display the preprint in perpetuity.

All rights reserved. No reuse allowed without permission.

between methylation and DDE exposure levels, whereas MIRLET7HBG showed a trend towards increased methylation with increasing DDE levels (Figure 7). Similarly, consistent but not significant increases in methylation at multiple $\mathrm{CpG}$ sites within SNORD115 were observed in the samples with higher exposures (Table 5). PTPRN2, on the other hand, showed no correlation between methylation detected by pyrosequencing and exposure levels.

\section{Comparison of DMR-associated genes from this study with those from ASD-related and unrelated methylation studies}

The DDE DMR-associated genes in sperm were compared to differentially methylated genes in a variety of tissues from studies on ASD-associated methylation differences. These tissues included cord blood from newborns, a fraction of whom was later diagnosed with ASD (Mordaunt et al., 2020), sperm (Feinberg et al., 2015) and placenta (Zhu et al., 2019) from parents of children with high risk for ASD, brain tissues from individuals with Dup 15q syndrome that is often associated with ASD (Dunaway et al., 2016) as well as lymphoblastoid cell lines derived from individuals with a severe form of ASD (Hu, Hong, Xu, \& Shu, 2020). Hypergeometric distribution analyses show that the DMR-associated genes from both the discovery and validation WGBS analyses overlapped significantly with those from ASD cord blood, paternal sperm, placenta, and Dup15q brain that also showed detectable PCB 95 exposures (Dunaway et al., 2016) (Table 6). DMR-associated genes from the discovery, but not validation, set also overlapped significantly with those from lymphoblastoid cell lines.

Interestingly, the significance of the overlap between the DDE DMR-associated genes is highest in DMRs identified from cord blood from children diagnosed with ASD and lower in the more differentiated or immortalized tissues, i.e., brain and lymphoblasts, respectively. In the study on placental methylation, placentas of high-risk mothers with a child (or children) already 
diagnosed with ASD were obtained after the birth of a subsequent child for WGBS analysis (Schroeder et al., 2016). Subsequent analysis of DMRs from the placentas for ASD outcome revealed 596 nominally significant genes, of which two (CYP2E1 and IRS2) reached genomewide significance (Zhu et al., 2019). For the sperm methylation analysis, semen samples from fathers of a child already diagnosed with ASD, were obtained for methylation analyses (Feinberg et al., 2015). The placenta and sperm studies revealed DMR-associated genes related to ASD outcome or higher risk for ASD, respectively, in offspring of the high-risk parents in comparison to parents of neurotypical children, while the DMR-associated genes in cord blood may be more directly related to ASD diagnosis in the individual. In addition, the DDE DMR-associated genes from both discovery and validation datasets significantly overlapped with those from pan-cancer studies (Su et al., 2018). The overlap with cancer genes is not surprising since organochlorine exposures are well-known risk factors for cancer; thus, the current study reveals exposureassociated epigenetic changes in DMR-associated genes that may also increase cancer risk (Dorgan et al., 1999; Jaga \& Dharmani, 2005; Purdue, Hoppin, Blair, Dosemeci, \& Alavanja, 2007). Interestingly, cancer and ASD share many risk genes and pathways (Crawley, Heyer, \& LaSalle, 2016), some of which may be influenced by environmental factors. On the other hand, there was no significant overlap of DDE DMR-related genes with those in cord blood from the Faroese population that were also associated with DDE exposures (Leung et al., 2018), although DMR-associated genes from both sperm (discovery set) and cord blood showed enrichment in multiple canonical pathways associated with neurological functions (Table 7). Comparison of the DMR-associated genes from the ASD and Faroese cord blood studies showed no significant overlap $(\mathrm{Q}=0.84)$, but both sets of DMRs were highly enriched in genes on the X-chromosome. Intriguingly, the X-linked genes from the ASD cord blood were predominantly found in females 
medRxiv preprint doi: https://doi.org/10.1101/2021.02.21.21252162; this version posted February 23, 2021. The copyright holder for this preprint

(which was not certified by peer review) is the author/funder, who has granted medRxiv a license to display the preprint in perpetuity.

All rights reserved. No reuse allowed without permission.

(Mordaunt et al., 2020), while those from the Faroese cord blood were exclusively male specific (Leung et al., 2018). By comparison, despite the highly significant overlap between the DMRassociated genes in the Faroese sperm and the ASD cord blood, there were relatively few Xlinked DMR-associated genes found in sperm. Collectively, these results suggest that exposure to persistent organic pollutants, such as DDE, is associated with altered methylation status of genes in sperm and early developmental tissues that are critically associated with ASD.

\section{Discussion}

\section{Methylation patterns of sperm DNA are associated with DDE exposure levels}

This study shows that the DNA methylation status in sperm may be influenced by lifelong exposure to environmentally derived persistent EDCs, such as DDE. The Faroese cohort used in this study is particularly exposed to higher than average levels of EDCs as a result of their natural diet which includes substantial amounts of pilot whale meat and blubber. Fatty tissues are reservoirs for lipophilic molecules, which include a wide variety of organochlorines, such as DDE as well as PCBs. The high correlation between the levels of multiple organochlorines and DDE in serum indicates that the DDE exposures employed in this study are proxies for exposures to persistent organochlorines in general. Although some of these compounds have now been banned for use, the long half-lives of such compounds and/or their breakdown products still pose risk of environmental exposures.

\section{DMRs harbor genes enriched for neurodevelopment and function}

Although there are hundreds of genes whose methylation is altered by elevated exposure to DDE and other organochlorines, our gene ontology and pathway analyses reveal that genes involved in nervous system development and function are among the most significantly overrepresented in DMRs. Moreover, a significant number of these genes are also autism risk genes 
that are included in the SFARI Gene database. Among the ASD-risk DMR-associated genes validated by pyrosequencing are CSMD1, NRXN2, and RBFOX1. CSMD1, which encodes for CUB and Sushi multiple domains 1, is highly expressed in brain tissues where it has been associated with neuronal growth cone stabilization and neuritogenesis (Molenaar et al., 2012). Aside from being a risk gene for ASD (Cukier et al., 2014; Guo et al., 2017; Hu, Addington, \& Hyman, 2011), it has also been implicated in schizophrenia, bipolar disorder, and post-traumatic stress disorder (Woo, Yu, Kumar, \& Reifman, 2017). NRXN2 codes for neurexin 2, a brainenriched cell adhesion molecule that has long been associated with ASD (Dachtler et al., 2015; Gauthier et al., 2011; Mohrmann, Gillessen-Kaesbach, Siebert, Caliebe, \& Hellenbroich, 2011). NRXN2 plays a role in early cortical synaptogenesis and axon guidance (Harkin et al., 2017). RBFOX1 encodes for RNA binding fox-1 homolog 1, a neuron-specific splicing factor that has been implicated in many studies on ASD (Bacchelli et al., 2020; Griswold et al., 2015; Martin et al., 2007). Interestingly, $R B F O X 1$ was one of the top transcriptional targets of the orphan nuclear hormone receptor RORA which we found to be regulated by sex hormones (Sarachana \& $\mathrm{Hu}$, 2013) as well as EDCs, including DDE and atrazine, an herbicide (Shu, Kocher, and $\mathrm{Hu}$, unpublished data).

\section{EDC-associated differential methylation also impacts noncoding regions of the genome}

MIRLET7BHG codes for a long noncoding RNA (lncRNA) whose neonatal umbilical cord methylation level has been associated with birth weight in a study of the effects of prenatal environment and genotype on offspring weight and obesity in early childhood (Lin et al., 2017). This gene was identified in this study as a potential predictor of exposure level by machinelearning analyses. Interestingly, this gene was one of eight lncRNAs that were differentially expressed between a group of women with polycystic ovary syndrome (PCOS) and control 
women, and the only one whose expression was correlated with BMI (Butler et al., 2019). As

PCOS is associated with abnormally high levels of male hormones, it is notable that the methylation status of $M I R L E T 7 B H G$ is influenced by EDC exposures.

The altered methylation in a large block on chromosome 15 encompassing the noncoding SNORD115 region is of particular interest inasmuch as this region was also found to be differentially methylated in the sperm of fathers with a child exhibiting ASD in comparison to the sperm of fathers of unaffected children (Feinberg et al., 2015). However, the origins of such differences in sperm DNA methylation that are associated with ASD are unknown. The results from this study suggest that environmental exposures to certain EDCs may in part be responsible for alterations in the sperm methylome and, in particular, the SNORD115 region. This region is imprinted maternally and normally shows compact heterochromatin until its expression, which is exclusive to neurons. Intriguingly, the SNORD115 locus is not expressed in any tissue besides the brain. With respect to function, the $S N O R D 115$ region on human chromosome $15 \mathrm{q} 11-\mathrm{q} 13$ contains a series of 48 highly conserved small nucleolar RNAs (snoRNAs) that participate in the modification of other noncoding RNAs and site-specific 2'-O-methylation of substrate RNAs (Galardi et al., 2002) as well as alternative splicing and RNA editing, especially of 5-HTR2C pre-mRNA (Bratkovič, Modic, Camargo Ortega, Drukker, \& Rogelj, 2018; Cavaillé, 2017; Raabe et al., 2019). In addition, a previous study has also identified alterations at this locus in association with exposures to EDCs, albeit of a more transient (non-persistent) nature. Specifically, increased methylation was observed in the SNORD115 locus in human fetal lung tissue of discontinued pregnancies of women exposed to BPA (Faulk et al., 2015).

Although deletions in this genomic region are associated with Prader-Willi syndrome (PWS), loss of SNORD115 alone is not sufficient to cause the disease (Bürger, Horn, Tönnies, 
Neitzel, \& Reis, 2002; Runte, Varon, Horn, Horsthemke, \& Buiting, 2005). Maternal duplications in the chr15q11-q13 region (aka. Dup15q syndrome) have also been associated with ASD as well as other developmental disorders, with some genes showing altered methylation status (Depienne et al., 2009; Finucane et al., 2016; Scoles, Urraca, Chadwick, Reiter, \& Lasalle, 2011). As mentioned earlier, Dup15q was shown to be a strong predictor of PCB 95 exposure (Mitchell et al., 2012). The Mitchell et al. study further showed that LINE-1 methylation was reduced in Dup 15q and PWS samples but not idiopathic ASD, suggesting gene $\mathrm{x}$ environment interactions possibly mediated through epigenetic modifications in the genetically defined but not idiopathic ASD. However, SNORD115 genes were not specifically implicated in these studies. Thus, the present study, coupled with that of Feinberg et al. on sperm from fathers of a child with ASD (Feinberg et al., 2015), reveals an additional epigenetic mechanism through which long-lived EDCs may mediate ASD-related changes in this region. Moreover, such changes in germline cells raise the possibility of transgenerational inheritance of phenotype as described in multiple animal studies.

\section{Potential significance of methylation changes in sperm cells}

Previous studies on animal models have reported transgenerational effects of EDC exposures on disease and behavioral phenotypes, some of which were shown to be mediated by epigenetic changes in the germline (Anway \& Skinner, 2008; Manikkam et al., 2012; McBirney et al., 2017; Skinner, Manikkam, \& Guerrero-Bosagna, 2011). Initial findings in rodents have shown that exposure to vinclozolin (an androgenic EDC) or methoxychlor (an estrogenic EDC) led to increased male infertility and related characteristics such as decreased sperm count in all subsequent generations, from F1 through F4 (Anway, Cupp, Uzumcu, \& Skinner, 2005). In addition, when gestating F0 females were given various doses of a mix of EDCs during 
medRxiv preprint doi: https://doi.org/10.1101/2021.02.21.21252162; this version posted February 23, 2021. The copyright holder for this preprint

(which was not certified by peer review) is the author/funder, who has granted medRxiv a license to display the preprint in perpetuity.

All rights reserved. No reuse allowed without permission.

embryonic development, F1 and F3 generations exhibited increased total disease. Differentially methylated regions were found in sperm of the the F3 generation that included promoters of genes associated with underlying diseases such as obesity, PCOS, and ovarian disease (Manikkam, Tracey, Guerrero-Bosagna, \& Skinner, 2013). These studies and others (McBirney et al., 2017) indicate that F0 exposure can lead to transgenerational effects on phenotypes that were associated with epigenetic changes in sperm that were specific to adult onset disease.

\section{Advantages and limitations of this study design and future directions}

A primary advantage of this study on sperm from men with different levels of exposure to DDE is that the Faroe Islands population is considered a "genetic isolate", thus reducing genetic heterogeneity that is often a major challenge in epigenetic studies. Another advantage is the natural Faroese diet, rich in pilot whale meat and blubber, that exposes the population to higher than average levels of persistent organochlorines. While we show differences in methylation patterns in sperm from men with high versus low exposures to DDE (which were highly correlated with the sum of the four most prevalent PCB congeners), an obvious limitation of this study is the lack of a completely unexposed set of samples for comparisons. Because EDCs are known to exhibit non-monotonic dose-response curves (Vandenberg et al., 2012), it is possible that the lowest exposures examined here may show even greater methylation differences relative to unexposed controls than the differences between the first and third exposure tertiles included in this study. Moreover, we were not able to correlate methylation changes with changes in gene expression in the same tissues inasmuch as spermatocytes are transcriptionally inactive. Additionally, we could not correlate EDC exposure with ASD risk in offspring, as there was no information on children (if any) of the men in this Faroese cohort. Such a study would be particularly interesting as it has been reported that neurobehavioral deficits in a Faroese birth 
cohort of 7-year-old children are associated with prenatal exposures to organochlorine neurotoxicants in seafood as measured in umbilical cord tissue (Grandjean et al., 2001). Aside from investigating the possible relationships between organochlorine exposures, sperm DNA methylation profiles, and neurodevelopmental disorders, the availability of this publicly accessible methylation data on DDE/organochlorine-associated changes in the sperm methylome of exposed individuals will nevertheless provide a valuable resource for studies on other diseases and conditions, such as cancer, obesity, diabetes, and infertility, which are also linked to environmental exposures.

Future studies should include additional cohorts sampled longitudinally to monitor temporal changes in individual sperm methylation levels as a function of cumulative EDC exposures as well as expanded concentration levels of DDE/organochlorines. Given the association between exposure levels of DDE and altered methylation of many neurodevelopmental genes, it will also be of interest to investigate the relationships between DDE exposures of the men, epigenetic changes in sperm, and the health outcomes of their children.

\section{Conclusions}

This study shows that elevated exposure to DDE, one of a class of persistent organochlorines, is associated with differential genome-wide DNA methylation patterns in sperm when compared against the lowest exposure levels. The DMRs are enriched for genes involved in many biological processes, including neurological functions and pathways impacted by neurodevelopmental disorders. This study thus supports the link between environmental EDC exposures and epigenetic changes in germ cells that may impact the regulation of many genes 
medRxiv preprint doi: https://doi.org/10.1101/2021.02.21.21252162; this version posted February 23, 2021. The copyright holder for this preprint (which was not certified by peer review) is the author/funder, who has granted medRxiv a license to display the preprint in perpetuity.

All rights reserved. No reuse allowed without permission.

associated with disease phenotypes, including ASD. Studies involving animal models have shown that DNA methylation patterns as well as associated phenotypes or diseases can be stably and heritably transmitted through the germline in several generations of offspring, specifically in relation to EDC exposure. It is unknown whether the DNA methylation differences noted in this study arose from direct exposure of the individual sperm donors to EDCs or from ancestral exposures that led to the inheritance of specific DNA methylation patterns in the donors' sperm.

\section{Acknowledgements}

This study was supported by the National Institute of Environmental Health Sciences of the National Institutes of Health (grant R21 ES028124 to VWH and partial support from R01 ES029213 to JML). BIL was supported by a Canadian Institutes of Health Research (CIHR) postdoctoral fellowship (MFE-146824) and a CIHR Banting postdoctoral fellowship (BPF162684). We thank Dr. Pál Weihe (Department of Occupational Medicine and Public Health,

Faroese Hospital System, Tórshavn, Faroe Islands) for generously providing the semen samples, demographic information on the semen donors, and data on serum levels of DDE and other organochlorines that had been determined previously by Dr. Philippe Grandjean (Department of Environmental Medicine, University of Southern Denmark, Odense, Denmark). We also thank Dr. Melissa Perry (Department of Environmental and Occupational Health, GWU) for dividing the semen samples from the Faroese cohort into exposure tertiles based on DDE serum levels which allowed us to process the samples upon receipt from sperm isolation through bisulfite sequencing without knowledge of the donor's exposure group. 
medRxiv preprint doi: https://doi.org/10.1101/2021.02.21.21252162; this version posted February 23, 2021. The copyright holder for this preprint (which was not certified by peer review) is the author/funder, who has granted medRxiv a license to display the preprint in perpetuity.

All rights reserved. No reuse allowed without permission.

\section{Authors' contributions}

AGM was responsible for sequence alignment, quality control, WGBS, and bioinformatics analyses of the DMRs. HTS was responsible for sample organization and preparation, including sperm and DNA isolation from the semen aliquots. BIL also contributed substantially to WGBS and bioinformatics analyses. HH performed the machine learning analysis. CB analyzed the pyrosequencing data. YL provided statistical support and advice. JML provided advice and discussion of the WGBS analysis and data interpretation. VWH conceived of the study, performed bioinformatics and hypergeometric analyses on the DMR-associated genes, and wrote the manuscript. AGM, BIL, and JML also contributed to manuscript preparation and editing. 


\section{References}

Abrahams, B. S., Arking, D. E., Campbell, D. B., Mefford, H. C., Morrow, E. M., Weiss, L. A., . . Packer, A. (2013). SFARI gene 2.0: A community-driven knowledgebase for the autism spectrum disorders (ASDs). Molecular Autism, 4(1) doi:10.1186/2040-2392-4-36

American Psychiatric Association. Task Force on DSM-5. (2013). Diagnostic and statistical manual of mental disorders (5th ed.). Arlington, VA: American Psychiatric Association Publishing.

Anway, M. D., Cupp, A. S., Uzumcu, N., \& Skinner, M. K. (2005). Toxicology: Epigenetic transgenerational actions of endocrine disruptors and male fertility. Science, 308(5727), 1466-1469.

Anway, M. D., \& Skinner, M. K. (2008). Epigenetic programming of the germ line: Effects of endocrine disruptors on the development of transgenerational disease. Reproductive BioMedicine Online, 16(1), 23-25.

Bacchelli, E., Cameli, C., Viggiano, M., Igliozzi, R., Mancini, A., Tancredi, R., . . Maestrini, E. (2020). An integrated analysis of rare CNV and exome variation in autism spectrum disorder using the infinium PsychArray. Scientific Reports, 10(1), 3198. doi:10.1038/s41598-020-59922-3

Bakulski, K. M., Singer, A. B., \& Fallin, M. D. (2014). Genes and environment in autism spectrum disorders: An integrated perspective. In V. W. Hu (Ed.), Frontiers in autism 
medRxiv preprint doi: https://doi.org/10.1101/2021.02.21.21252162; this version posted February 23, 2021. The copyright holder for this preprint

(which was not certified by peer review) is the author/funder, who has granted medRxiv a license to display the preprint in perpetuity.

All rights reserved. No reuse allowed without permission.

research: New horizons for diagnosis and treatment (pp. 335-374). Singapore: World Scientific Pubishing Co. doi:10.1142/9789814602167_0014

Baron-Cohen, S., Auyeung, B., Nørgaard-Pedersen, B., Hougaard, D. M., Abdallah, M. W., Melgaard, L., .. . Lombardo, M. V. (2014). Elevated fetal steroidogenic activity in autism. Molecular Psychiatry, , 1-8.

Bratkovič, T., Modic, M., Camargo Ortega, G., Drukker, M., \& Rogelj, B. (2018). Neuronal differentiation induces SNORD115 expression and is accompanied by post-transcriptional changes of serotonin receptor 2c mRNA. Scientific Reports, 8(1) doi:10.1038/s41598-01823293-7

Braun, J. M. (2017). Early-life exposure to EDCs: Role in childhood obesity and neurodevelopment. Nature Reviews Endocrinology, 13(3), 161-173. doi:10.1038/nrendo.2016.186

Bürger, J., Horn, D., Tönnies, H., Neitzel, H., \& Reis, A. (2002). Familial interstitial 570 kbp deletion of the UBE3A gene region causing angelman syndrome but not prader-willi syndrome. American Journal of Medical Genetics, 111(3), 233-237. doi:10.1002/ajmg.10498

Butler, A. E., Hayat, S., Dargham, S. R., Malek, J. A., Abdulla, S. A., Mohamoud, Y. A., . . Atkin, S. L. (2019). Alterations in long noncoding RNAs in women with and without polycystic ovarian syndrome. Clinical Endocrinology, 91(6), 793-797.

doi:10.1111/cen.14087 
medRxiv preprint doi: https://doi.org/10.1101/2021.02.21.21252162; this version posted February 23, 2021. The copyright holder for this preprint

(which was not certified by peer review) is the author/funder, who has granted medRxiv a license to display the preprint in perpetuity.

All rights reserved. No reuse allowed without permission.

Cavaillé, J. (2017). Box C/D small nucleolar RNA genes and the prader-willi syndrome: A complex interplay. Wiley Interdisciplinary Reviews: $R N A$, 8(4) doi:10.1002/wrna.1417

Cavalcante, R. G., \& Sartor, M. A. (2017). Annotatr: Genomic regions in context.

Bioinformatics, 33(15), 2381-2383. doi:10.1093/bioinformatics/btx183

Crawley, J. N., Heyer, W. -., \& LaSalle, J. M. (2016). Autism and cancer share risk genes, pathways, and drug targets. Trends in Genetics, 32(3), 139-146.

doi:10.1016/j.tig.2016.01.001

Cukier, H. N., Dueker, N. D., Slifer, S. H., Lee, J. M., Whitehead, P. L., Lalanne, E., . . PericakVance, M. A. (2014). Exome sequencing of extended families with autism reveals genes shared across neurodevelopmental and neuropsychiatric disorders. Molecular Autism, 5(1) doi:10.1186/2040-2392-5-1

Dachtler, J., Ivorra, J. L., Rowland, T. E., Lever, C., John Rodgers, R., \& Clapcote, S. J. (2015). Heterozygous deletion of $\alpha$-neurexin I or $\alpha$-neurexin II results in behaviors relevant to autism and schizophrenia. Behavioral Neuroscience, 129(6), 765-776. doi:10.1037/bne0000108

Das, P., Roychowdhury, A., Das, S., Roychoudhury, S., \& Tripathy, S. (2020). sigFeature: Novel significant feature selection method for classification of gene expression data using support vector machine and t statistic. Frontiers in Genetics, 11 doi:10.3389/fgene.2020.00247 
De Coster, S., \& Van Larebeke, N. (2012). Endocrine-disrupting chemicals: Associated disorders and mechanisms of action. Journal of Environmental and Public Health, 2012 doi: $10.1155 / 2012 / 713696$

Degenhardt, F., Seifert, S., \& Szymczak, S. (2019). Evaluation of variable selection methods for random forests and omics data sets. Briefings in Bioinformatics, 20(2), 492-503. doi:10.1093/bib/bbx124

Depienne, C., Moreno-De-Luca, D., Heron, D., Bouteiller, D., Gennetier, A., Delorme, R., .. . Betancur, C. (2009). Screening for genomic rearrangements and methylation abnormalities of the 15q11-q13 region in autism spectrum disorders. Biological Psychiatry, 66(4), 349359. doi:10.1016/j.biopsych.2009.01.025

Dorgan, J. F., Brock, J. W., Rothman, N., Needham, L. L., Miller, R., Stephenson Jr., H. E., . . . Taylor, P. R. (1999). Serum organochlorine pesticides and PCBs and breast cancer risk: Results from a prospective analysis (USA). Cancer Causes and Control, 10(1), 1-11. doi:10.1023/A:1008824131727

Dunaway, K. W., Islam, M. S., Coulson, R. L., Lopez, S. J., Vogel Ciernia, A., Chu, R. G., . . . LaSalle, J. M. (2016). Cumulative impact of polychlorinated biphenyl and large chromosomal duplications on DNA methylation, chromatin, and expression of autism candidate genes. Cell Reports, 17(11), 3035-3048. doi:10.1016/j.celrep.2016.11.058

Eskenazi, B., Rauch, S. A., Tenerelli, R., Huen, K., Holland, N. T., Lustig, R. H., .. . Harley, K. G. (2017). In utero and childhood DDT, DDE, PBDE and PCBs exposure and sex hormones 
medRxiv preprint doi: https://doi.org/10.1101/2021.02.21.21252162; this version posted February 23, 2021. The copyright holder for this preprint

(which was not certified by peer review) is the author/funder, who has granted medRxiv a license to display the preprint in perpetuity.

All rights reserved. No reuse allowed without permission.

in adolescent boys: The CHAMACOS study. International Journal of Hygiene and Environmental Health, 220(2), 364-372. doi:10.1016/j.ijheh.2016.11.001

Faulk, C., Kim, J. H., Jones, T. R., McEachin, R. C., Nahar, M. S., Dolinoy, D. C., \& Sartor, M. A. (2015). Bisphenol A-associated alterations in genome-wide DNA methylation and gene expression patterns reveal sequence-dependent and non-monotonic effects in human fetal liver. Environmental Epigenetics, 1(1), dvv006. doi:https://doi.org/10.1093/eep/dvv006

Feinberg, J. I., Bakulski, K. M., Jaffe, A. E., Tryggvadottir, R., Brown, S. C., Goldman, L. R., . . . Feinberg, A. P. (2015). Paternal sperm DNA methylation associated with early signs of autism risk in an autism-enriched cohort. International Journal of Epidemiology, Apr. 14, 112.

Finucane, B. M., Lusk, L., Arkilo, D., Chamberlain, S., Devinsky, O., Dindot, S., . . Cook, E. H. (2016). 15q duplication syndrome and related disorders. In M. P. Adam, H. H. Ardinger, R. A. Pagon, S. E. Wallace, L. J. H. Bean, K. Stephens \& A. Amemiya (Eds.), GeneReviews (internet) (2016th ed., ). Internet: University of Washington, Seattle, WA. Retrieved from https://www.ncbi.nlm.nih.gov/books/NBK367946/

Galardi, S., Fatica, A., Bachi, A., Scaloni, A., Presutti, C., \& Bozzoni, I. (2002). Purified box C/D snoRNPs are able to reproduce site-specific 2'-O-methylation of target RNA in vitro. Molecular and Cellular Biology, 22(19), 6663-6668. doi:10.1128/MCB.22.19.66636668.2002 
medRxiv preprint doi: https://doi.org/10.1101/2021.02.21.21252162; this version posted February 23, 2021. The copyright holder for this preprint

(which was not certified by peer review) is the author/funder, who has granted medRxiv a license to display the preprint in perpetuity.

All rights reserved. No reuse allowed without permission.

Garrido, N., Cruz, F., Egea, R. R., Simon, C., Sadler-Riggleman, I., Beck, D., ...Skinner, M. K. (2021). Sperm DNA methylation epimutation biomarker for ppaternal offspring autism susceptibility. Clin. Epigenet., 13:6. doi:10.1186/s13148-020-00995-2

Gauthier, J., Siddiqui, T. J., Huashan, P., Yokomaku, D., Hamdan, F. F., Champagne, N., .. . Rouleau, G. A. (2011). Truncating mutations in NRXN2 and NRXN1 in autism spectrum disorders and schizophrenia. Human Genetics, 130(4), 563-573. doi:10.1007/s00439-0110975-Z

Gogolla, N., LeBlanc, J. J., Quast, K. B., Sudhof, T. C., Fagiolini, M., \& Hensch, T. K. (2009). Common circuit defect of excitatory-inhibitory balance in mouse models of autism. $J$. Neurodev. Disord. 1(2), 172-181. doi:10.1007/s11689-009-9023-x

Gore, A. C., Martien, K. M., Gagnidze, K., \& Pfaff, D. (2014). Implications of prenatal steroid perturbations for neurodevelopment, behavior, and autism. Endocrine Reviews, 35(6), 961991. doi:10.1210/er.2013-1122

Grafodatskaya, D., Chung, B., Szatmari, P., \& Weksberg, R. (2010). Autism spectrum disorders and epigenetics. Journal of the American Academy of Child and Adolescent Psychiatry,

Grandjean, P., Weihe, P., Burse, V. W., Needham, L. L., Storr-Hansen, E., Heinzow, B., .. . White, R. F. (2001a). Neurobehavioral deficits associated with PCB in 7-year-old children prenatally exposed to seafood neurotoxicants. Neurotoxicology and Teratology, 23(4), 305317. doi:10.1016/S0892-0362(01)00155-6 
medRxiv preprint doi: https://doi.org/10.1101/2021.02.21.21252162; this version posted February 23, 2021. The copyright holder for this preprint

(which was not certified by peer review) is the author/funder, who has granted medRxiv a license to display the preprint in perpetuity.

All rights reserved. No reuse allowed without permission.

Griswold, A. J., Dueker, N. D., Van Booven, D., Rantus, J. A., Jaworski, J. M., Slifer, S. H., . . . Pericak-Vance, M. A. (2015). Targeted massively parallel sequencing of autism spectrum disorder-associated genes in a case control cohort reveals rare loss-of-function risk variants. Molecular Autism, 6(1) doi:10.1186/s13229-015-0034-z

Grote, S. (2020). GOfuncR: Gene ontology enrichment using FUNC. R package version 1.8.0 [computer software]. https://bioconductor.riken.jp/packages/release/bioc/html/GOfuncR.html: Bioconductor version: Release 3.11.

Gu, Z. (2014). rGREAT: Client for GREAT analysis. R package version 1.0.0 [computer software]. https://github.com/jokergoo/rGREAT: Bioconductor version: Release 3.1.

Guo, H., Peng, Y., Hu, Z., Li, Y., Xun, G., Ou, J., . . Xia, K. (2017). Genome-wide copy number variation analysis in a chinese autism spectrum disorder cohort. Scientific Reports, 7 doi:10.1038/srep44155

Hallmayer, J., Cleveland, S., Torres, A., Phillips, J., Cohen, B., Torigoe, T., . . Risch, N. (2011). Genetic heritability and shared environmental factors among twin pairs with autism. Archives of General Psychiatry, 68(11), 1095-1102.

Hansen, K. D., Langmead, B., \& Irizarry, R. A. (2012). BSmooth: From whole genome bisulfite sequencing reads to differentially methylated regions. Genome Biology, 13(10) doi:10.1186/gb-2012-13-10-R83 
Harkin, L. F., Lindsay, S. J., Xu, Y., Alzu'Bi, A., Ferrara, A., Gullon, E. A., . . Clowry, G. J. (2017). Neurexins 1-3 each have a distinct pattern of expression in the early developing human cerebral cortex. Cerebral Cortex, 27(1), 216-232. doi:10.1093/cercor/bhw394

Hu, V. W., Hong, Y., Xu, M., \& Shu, H. T. (2020). Altered DNA methylation in a severe subtype of idiopathic autism: Evidence for sex differences in affected metabolic pathways. Autism : The International Journal of Research and Practice, in press doi: $10.1177 / 1362361320971085$

$\mathrm{Hu}, \mathrm{V} . \mathrm{W}$. (2012). Is retinoic acid-related orphan receptor-alpha (RORA) a target for geneenvironment interactions contributing to autism? Neurotoxicology, 33(6), 1434-1435.

Hu, V. W., Addington, A., \& Hyman, A. (2011). Novel autism subtype-dependent genetic variants are revealed by quantitative trait and subphenotype association analyses of published GWAS data. PLoS ONE, 6(4)

Hu, V. W., Frank, B. C., Heine, S., Lee, N. H., \& Quackenbush, J. (2006). Gene expression profiling of lymphoblastoid cell lines from monozygotic twins discordant in severity of autism reveals differential regulation of neurologically relevant genes. BMC Genomics, 7, 118.

Hu, V. W., Nguyen, A., Kim, K. S., Steinberg, M. E., Sarachana, T., Scully, M. A., . . Lee, N. H. (2009). Gene expression profiling of lymphoblasts from autistic and nonaffected sib pairs: Altered pathways in neuronal development and steroid biosynthesis. PloS One, 4(6), e5775. doi:10.1371/journal.pone.0005775 
medRxiv preprint doi: https://doi.org/10.1101/2021.02.21.21252162; this version posted February 23, 2021. The copyright holder for this preprint

(which was not certified by peer review) is the author/funder, who has granted medRxiv a license to display the preprint in perpetuity.

All rights reserved. No reuse allowed without permission.

Jaga, K., \& Dharmani, C. (2005). The epidemiology of pesticide exposure and cancer: A review. Reviews on Environmental Health, 20(1), 15-38. doi:10.1515/REVEH.2005.20.1.15

Jenkins, T. G., Aston, K. I., Pflueger, C., Cairns, B. R., \& Carrell, D. T. (2014). Age-associated sperm DNA methylation alterations: Possible implications in offspring disease susceptibility. PLoS Genetics, 10(7)

Korthauer, K., Chakraborty, S., Benjamini, Y., \& Irizarry, R. A. (2019). Detection and accurate false discovery rate control of differentially methylated regions from whole genome bisulfite sequencing. Biostatistics, 20(3), 367-383. doi:10.1093/biostatistics/kxy007

Krueger, F., \& Andrews, S. R. (2011). Bismark: A flexible aligner and methylation caller for bisulfite-seq applications. Bioinformatics, 27(11), 1571-1572. doi:10.1093/bioinformatics/btr167

Kursa, M. B., \& Rudnicki, W. R. (2010). Feature selection with the boruta package. Journal of Statistical Software, 36(11), 1-13. doi:10.18637/jss.v036.i11

Lasalle, J. M. (2013). Epigenomic strategies at the interface of genetic and environmental risk factors for autism. Journal of Human Genetics, 58(7), 396-401. doi:10.1038/jhg.2013.49

Laufer, B. I., Hwang, H., Vogel Ciernia, A., Mordaunt, C. E., \& LaSalle, J. M. (2019). Whole genome bisulfite sequencing of down syndrome brain reveals regional DNA hypermethylation and novel disorder insights. Epigenetics, 14(7), 672-684. doi:10.1080/15592294.2019.1609867 
Leung, Y. -., Ouyang, B., Niu, L., Xie, C., Ying, J., Medvedovic, M., . . Ho, S. -. (2018).

Identification of sex-specific DNA methylation changes driven by specific chemicals in cord blood in a faroese birth cohort. Epigenetics, 13(3), 290-300.

doi:10.1080/15592294.2018.1445901

Lichtensteiger, W., Bassetti-Gaille, C., Faass, O., Axelstad, M., Boberg, J., Christiansen, S., .. . Schlumpf, M. (2015). Differential gene expression patterns in developing sexually dimorphic rat brain regions exposed to antiandrogenic, estrogenic, or complex endocrine disruptor mixtures: Glutamatergic synapses as target. Endocrinology, 156(4), 1477-1493. doi:10.1210/en.2014-1504

Lin, X., Lim, I. Y., Wu, Y., Teh, A. L., Chen, L., Aris, I. M., . . Yeo, G. S. H. (2017). Developmental pathways to adiposity begin before birth and are influenced by genotype, prenatal environment and epigenome. BMC Medicine, 15(1) doi:10.1186/s12916-017-08001

Maenner, M. J., Shaw, K. A., Baio, J., Washington, A., Patrick, M., DiRienzo, M., .. . Dietz, P. M. (2020). Prevalence of autism spectrum disorder among children aged 8 years-autism and developmental disabilities monitoring network, 11 sites, united states, 2016. MMWR Surveillance Summaries, 69(4), 1-12. doi:10.15585/MMWR.SS6904A1

Manikkam, M., Guerrero-Bosagna, C., Tracey, R., Haque, M. M., \& Skinner, M. K. (2012). Transgenerational actions of environmental compounds on reproductive disease and identification of epigenetic biomarkers of ancestral exposures. PLoS ONE, 7(2) 
Manikkam, M., Tracey, R., Guerrero-Bosagna, C., \& Skinner, M. K. (2013). Plastics derived endocrine disruptors (BPA, DEHP and DBP) induce epigenetic transgenerational inheritance of obesity, reproductive disease and sperm epimutations. PLoS ONE, 8(1) doi:10.1371/journal.pone.0055387

Martin, C. L., Duvall, J. A., Ilkin, Y., Simon, J. S., Arreaza, M. G., Wilkes, K., . . Geschwind, D. H. (2007). Cytogenetic and molecular characterization of A2BP1/FOX1 as a candidate gene for autism. Am JMed Genet B Neuropsychiatr Genet,

McAuliffe, M. E., Williams, P. L., Korrick, S. A., Altshul, L. M., \& Perry, M. J. (2012). Environmental exposure to polychlorinated biphenyls and p,p '-DDE and sperm sexchromosome disomy. Environmental Health Perspectives, 120(4), 535-540.

McBirney, M., King, S. E., Pappalardo, M., Houser, E., Unkefer, M., Nilsson, E., . . Skinner, M. K. (2017). Atrazine induced epigenetic transgenerational inheritance of disease, lean phenotype and sperm epimutation pathology biomarkers. PLoS ONE, 12, e0184306.

Milekic, M. H., Xin, Y., O'Donnell, A., Kumar, K. K., Bradley-Moore, M., Malaspina, D., .. . Gingrich, J. A. (2014). Age-related sperm DNA methylation changes are transmitted to offspring and associated with abnormal behavior and dysregulated gene expression. Molecular Psychiatry,

Mitchell, M. M., Woods, R., Chi, L. -., Schmidt, R. J., Pessah, I. N., Kostyniak, P. J., \& Lasalle, J. M. (2012). Levels of select PCB and PBDE congeners in human postmortem brain reveal possible environmental involvement in 15q11-q13 duplication autism spectrum disorder. Environmental and Molecular Mutagenesis, 53(8), 589-598. 
Mohrmann, I., Gillessen-Kaesbach, G., Siebert, R., Caliebe, A., \& Hellenbroich, Y. (2011). A de novo $0.57 \mathrm{mb}$ microdeletion in chromosome 11q13.1 in a patient with speech problems, autistic traits, dysmorphic features and multiple endocrine neoplasia type 1. European Journal of Medical Genetics, 54(4), e461-e464. doi:10.1016/j.ejmg.2011.04.006

Molenaar, J. J., Koster, J., Zwijnenburg, D. A., Van Sluis, P., Valentijn, L. J., Van Der Ploeg, I., . . . Versteeg, R. (2012). Sequencing of neuroblastoma identifies chromothripsis and defects in neuritogenesis genes. Nature, 483(7391), 589-593. doi:10.1038/nature10910

Moosa, A., Shu, H., Sarachana, T., \& Hu, V. W. (2018). Are endocrine disrupting compounds environmental risk factors for autism spectrum disorder? Hormones and Behavior, 101, 1321. doi:10.1016/j.yhbeh.2017.10.003

Mordaunt, C. E., Jianu, J. M., Laufer, B. I., Zhu, Y., Hwang, H., Dunaway, K. W., . . LaSalle, J. M. (2020). Cord blood DNA methylome in newborns later diagnosed with autism spectrum disorder reflects early dysregulation of neurodevelopmental and X-linked genes. Genome Medicine, 12(1) doi:10.1186/s13073-020-00785-8

Nevison, C. D. (2014). A comparison of temporal trends in united states autism prevalence to trends in suspected environmental factors. Environmental Health: A Global Access Science Source, 13(1) doi:10.1186/1476-069X-13-73

Nguyen, A., Rauch, T. A., Pfeifer, G. P., \& Hu, V. W. (2010). Global methylation profiling of lymphoblastoid cell lines reveals epigenetic contributions to autism spectrum disorders and a novel autism candidate gene, RORA, whose protein product is reduced in autistic brain. 
medRxiv preprint doi: https://doi.org/10.1101/2021.02.21.21252162; this version posted February 23, 2021. The copyright holder for this preprint

(which was not certified by peer review) is the author/funder, who has granted medRxiv a license to display the preprint in perpetuity.

All rights reserved. No reuse allowed without permission.

The FASEB Journal : Official Publication of the Federation of American Societies for

Experimental Biology, 24(8), 3036-3051. doi:10.1096/fj.10-154484

Oliveros, J. C. (2007). Venny. an interactive tool for comparing lists with venn's diagrams. http://bioinfogp.cnb.csic.es/tools/venny/index.html

Perry, M. J., Young, H. A., Grandjean, P., Halling, J., Petersen, M. S., Martenies, S. E., .. . Weihe, P. (2016). Sperm aneuploidy in faroese men with lifetime exposure to dichlorodiphenyldichloroethylenchandigarhe $\left(\mathrm{P}, \mathrm{p}^{\prime}-\mathrm{DDE}\right)$ and polychlorinated biphenyl (PCB) pollutants. Environmental Health Perspectives, 124(7), 951-956.

doi:10.1289/ehp.1509779

Purdue, M. P., Hoppin, J. A., Blair, A., Dosemeci, M., \& Alavanja, M. C. R. (2007). Occupational exposure to organochlorine insecticides and cancer incidence in the agricultural health study. International Journal of Cancer, 120(3), 642-649. doi:10.1002/ijc.22258

Quinlan, C. A., McVeigh, K. H., Driver, C. R., Govind, P., \& Karpati, A. (2015). Parental age and autism spectrum disorders among new york city children 0-36 months of age. Maternal and Child Health Journal,

Raabe, C. A., Voss, R., Kummerfeld, D. -., Brosius, J., Galiveti, C. R., Wolters, A., .. . Rozhdestvensky, T. S. (2019). Ectopic expression of Snord115 in choroid plexus interferes with editing but not splicing of 5-Ht2c receptor pre-mRNA in mice. Scientific Reports, 9(1) doi:10.1038/s41598-019-39940-6 
medRxiv preprint doi: https://doi.org/10.1101/2021.02.21.21252162; this version posted February 23, 2021. The copyright holder for this preprint

(which was not certified by peer review) is the author/funder, who has granted medRxiv a license to display the preprint in perpetuity.

All rights reserved. No reuse allowed without permission.

Rangasamy, S., D'Mello, S. R., \& Narayanan, V. (2013). Epigenetics, autism spectrum, and neurodevelopmental disorders. Neurotherapeutics, 10(4), 742-756. doi:10.1007/s13311013-0227-0

Reichenberg, A., Gross, R., Weiser, M., Bresnahan, M., Silverman, J., Harlap, S., . . Susser, E. (2006). Advancing paternal age and autism. Arch Gen Psychiatry, 63(9), 1026-32.

Rignell-Hydbom, A., Rylander, L., Giwercman, A., Jönsson, B. A. G., Lindh, C., Eleuteri, P., .. . Hagmar, L. (2005). Exposure to PCBs and p,p'-DDE and human sperm chromatin integrity. Environmental Health Perspectives, 113(2), 175-179. doi:10.1289/ehp.7252

Rivollier, F., Krebs, M. -., \& Kebir, O. (2019). Perinatal exposure to environmental endocrine disruptors in the emergence of neurodevelopmental psychiatric diseases: A systematic review. International Journal of Environmental Research and Public Health, 16(8) doi:10.3390/ijerph16081318

Runte, M., Varon, R., Horn, D., Horsthemke, B., \& Buiting, K. (2005). Exclusion of the C/D box snoRNA gene cluster HBII-52 from a major role in prader-willi syndrome. Human Genetics, 116(3), 228-230. doi:10.1007/s00439-004-1219-2

Sarachana, T., \& Hu, V. W. (2013). Genome-wide identification of transcriptional targets of RORA reveals direct regulation of multiple genes associated with autism spectrum disorder. Molecular Autism, 4(1) 
Sarachana, T., Xu, M., Wu, R. -., \& Hu, V. W. (2011). Sex hormones in autism: Androgens and estrogens differentially and reciprocally regulate RORA, a novel candidate gene for autism. PLoS ONE, 6(2), e17116.

Schroeder, D. I., Schmidt, R. J., Crary-Dooley, F. K., Walker, C. K., Ozonoff, S., Tancredi, D. J., . . LaSalle, J. M. (2016). Placental methylome analysis from a prospective autism study. Molecular Autism, 7(1) doi:10.1186/s13229-016-0114-8

Schug, T. T., Blawas, A. M., Gray, K., Heindel, J. J., \& Lawler, C. P. (2015). Elucidating the links between endocrine disruptors and neurodevelopment. Endocrinology, 156(6), 19411951.

Scoles, H. A., Urraca, N., Chadwick, S. W., Reiter, L. T., \& Lasalle, J. M. (2011). Increased copy number for methylated maternal $15 \mathrm{q}$ duplications leads to changes in gene and protein expression in human cortical samples. Molecular Autism, 2(1)

Sethi, S., Keil, K. P., Chen, H., Hayakawa, K., Li, X., Lin, Y., . . Lein, P. J. (2017). Detection of 3,3'-dichlorobiphenyl in human maternal plasma and its effects on axonal and dendritic growth in primary rat neurons. Toxicological Sciences, 158(2), 401-411. doi:10.1093/toxsci/kfx 100

Simon Baron-Cohen, a., Knickmeyer, R. C., \& Belmonte, M. K. (2005). Sex differences in the brain: Implications for explaining autism. Science, (5749), 819.

Skinner, M. K., Manikkam, M., \& Guerrero-Bosagna, C. (2011). Epigenetic transgenerational actions of endocrine disruptors doi://dx.doi.org/10.1016/j.reprotox.2010.10.012 
medRxiv preprint doi: https://doi.org/10.1101/2021.02.21.21252162; this version posted February 23, 2021. The copyright holder for this preprint

(which was not certified by peer review) is the author/funder, who has granted medRxiv a license to display the preprint in perpetuity.

All rights reserved. No reuse allowed without permission.

Su, J., Huang, Y. -., Cui, X., Wang, X., Zhang, X., Lei, Y., . . Li, W. (2018). Homeobox oncogene activation by pan-cancer DNA hypermethylation. Genome Biology, 19(1) doi:10.1186/s13059-018-1492-3

Supek, F., Bošnjak, M., Škunca, N., \& Šmuc, T. (2011). Revigo summarizes and visualizes long lists of gene ontology terms. PLoS ONE, 6(7) doi:10.1371/journal.pone.0021800

Szklarczyk, D., Gable, A. L., Lyon, D., Junge, A., Wyder, S., Huerta-Cepas, J., . . Von Mering, C. (2019). STRING v11: Protein-protein association networks with increased coverage, supporting functional discovery in genome-wide experimental datasets. Nucleic Acids Research, 47(D1), D607-D613. doi:10.1093/nar/gky1131

Tordjman, S., Somogyi, e., Coulon, N., Kermarrec, S., Cohen, D., Bronsard, G., . . Xavier, J. (2014). Gene X environment interactions in autism spectrum disorders: Role of epigenetic mechanisms. Frontiers in Psychiatry, Vol 5 (2014), doi:10.3389/fpsyt.2014.00053/full; $10.3389 /$ fpsyt.2014.00053

Tran, N. Q. V., \& Miyake, K. (2017). Neurodevelopmental disorders and environmental toxicants: Epigenetics as an underlying mechanism. International Journal of Genomics, 2017 doi:10.1155/2017/7526592

Vandenberg, L. N., Colborn, T., Hayes, T. B., Heindel, J. J., Jacobs,David R.,„Jr, Lee, D., . . . Myers, J. P. (2012). Hormones and endocrine-disrupting chemicals: Low-dose effects and nonmonotonic dose responses. Endocrine Reviews, 33(3), 378-455. doi:10.1210/er.20111050 
medRxiv preprint doi: https://doi.org/10.1101/2021.02.21.21252162; this version posted February 23, 2021. The copyright holder for this preprint

(which was not certified by peer review) is the author/funder, who has granted medRxiv a license to display the preprint in perpetuity.

All rights reserved. No reuse allowed without permission.

Vierck, E., \& Silverman, J. M. (2014). Brief report: Phenotypic differences and their relationship to paternal age and gender in autism spectrum disorder. Journal of Autism and Developmental Disorders, 45(6), 1915-1924.

Wolstenholme, J. J., Goldsby, J. A., \& Rissman, E. F. (2013). Transgenerational effects of prenatal bisphenol A on social recognition. Hormones and Behavior, 64(5), 839; 839.

Woo, H. J., Yu, C., Kumar, K., \& Reifman, J. (2017). Large-scale interaction effects reveal missing heritability in schizophrenia, bipolar disorder and posttraumatic stress disorder. Translational Psychiatry, 7(4) doi:10.1038/tp.2017.61

Wu, H., de Gannes, M. K., Luchetti, G., \& Richard Pilsner, J. (2015). Rapid method for the isolation of mammalian sperm DNA. BioTechniques, 58(6), 293-300. doi:10.2144/000114280

Wu, H., Hauser, R., Krawetz, S. A., \& Pilsner, J. R. (2015). Environmental susceptibility of the sperm epigenome during windows of male germ cell development. Current Environmental Health Reports, 2(4), 356-366. doi:10.1007/s40572-015-0067-7

Zhu, Y., Mordaunt, C. E., Yasui, D. H., Marathe, R., Coulson, R. L., Dunaway, K. W., ... Lasalle, J. M. (2019). Placental DNA methylation levels at CYP2E1 and IRS2 are associated with child outcome in a prospective autism study. Human Molecular Genetics, 28(16), 2659. doi:10.1093/hmg/ddz084 
medRxiv preprint doi: https://doi.org/10.1101/2021.02.21.21252162; this version posted February 23, 2021. The copyright holder for this preprint (which was not certified by peer review) is the author/funder, who has granted medRxiv a license to display the preprint in perpetuity.

All rights reserved. No reuse allowed without permission.

Table 1. Gene ontology terms enriched among DDE DMR-associated genes from discovery and validation sets

\begin{tabular}{|c|c|c|c|}
\hline GO ID & Pathway description & Discovery FDF - & Validation FDR \\
\hline GO.0007399 & nervous system development & $1.80 \mathrm{E}-11$ & $4.80 \mathrm{E}-03$ \\
\hline GO.0007275 & multicellular organism development & $2.13 E-08$ & $1.60 \mathrm{E}-03$ \\
\hline GO.0048731 & system development & $3.14 \mathrm{E}-08$ & 4.10E-03 \\
\hline GO.0048856 & anatomical structure development & 7.91E-08 & $2.20 \mathrm{E}-03$ \\
\hline GO.0022008 & neurogenesis & 5.51E-07 & 2.19E-02 \\
\hline GO.0032502 & developmental process & 5.51E-07 & 5.50E-04 \\
\hline GO.0048699 & generation of neurons & 5.51E-07 & 1.17E-02 \\
\hline G0.0048666 & neuron development & $1.55 \mathrm{E}-06$ & $4.12 \mathrm{E}-02$ \\
\hline G0.0030182 & neuron differentiation & $2.95 \mathrm{E}-06$ & $2.19 \mathrm{E}-02$ \\
\hline GO.0000904 & cell morphogenesis involved in differentiation & 1.03E-05 & 3.89E-02 \\
\hline GO.0048468 & cell development & 2.77E-05 & $1.48 \mathrm{E}-02$ \\
\hline GO.0030154 & cell differentiation & $1.50 \mathrm{E}-04$ & 2.19E-02 \\
\hline GO.0048869 & cellular developmental process & 2.50E-04 & $1.45 \mathrm{E}-02$ \\
\hline GO.0048513 & animal organ development & 2.80E-04 & $1.92 \mathrm{E}-02$ \\
\hline GO.0003279 & cardiac septum development & 7.10E-04 & 3.89E-02 \\
\hline GO.0050808 & synapse organization & $1.80 \mathrm{E}-03$ & 4.18E-02 \\
\hline GO.0072359 & circulatory system development & $1.80 \mathrm{E}-03$ & 4.12E-02 \\
\hline GO.0007155 & cell adhesion & 2.40E-03 & $9.60 \mathrm{E}-03$ \\
\hline GO.0003148 & outflow tract septum morphogenesis & $3.30 \mathrm{E}-03$ & 2.74E-02 \\
\hline GO.0050793 & regulation of developmental process & 4.10E-03 & 2.60E-02 \\
\hline GO.0050794 & regulation of cellular process & $5.80 \mathrm{E}-03$ & $1.90 \mathrm{E}-04$ \\
\hline GO.0000122 & negative regulation of transcription by RNA polymerase II & $6.10 \mathrm{E}-03$ & $7.70 \mathrm{E}-04$ \\
\hline GO.2000026 & regulation of multicellular organismal development & $6.10 \mathrm{E}-03$ & 3.89E-02 \\
\hline GO.0050789 & regulation of biological process & $1.04 \mathrm{E}-02$ & $3.30 \mathrm{E}-04$ \\
\hline G0.0006928 & movement of cell or subcellular component & $1.50 \mathrm{E}-02$ & $2.19 \mathrm{E}-02$ \\
\hline GO.0007423 & sensory organ development & $1.50 \mathrm{E}-02$ & $1.05 \mathrm{E}-02$ \\
\hline GO.0048518 & positive regulation of biological process & 3.04E-02 & 3.80E-04 \\
\hline GO.0050767 & regulation of neurogenesis & 4.36E-02 & $4.12 \mathrm{E}-02$ \\
\hline GO.0051960 & regulation of nervous system development & 4.54E-02 & $3.51 \mathrm{E}-02$ \\
\hline
\end{tabular}




\section{Table 2. Canonical pathways enriched among DDE DMR-associated genes from discovery and validation sets}

\begin{tabular}{|c|c|c|}
\hline Canonical Pathways (Discovery) & $-\log (p \text {-value })^{*}$ & Molecules \\
\hline CREB Signaling in Neurons & 6.18 & $\begin{array}{l}\text { CACNA1I,CACNG6,GRID2,GRIA1,GRIK3,GNG2,FLT3,CACNB4,PIK3C2G,G } \\
\text { NAI1,FGFR2,CREB5,GNG7,CACNA1A,GRM5,SHC1,GNAO1,IRS2,PRKCH,G } \\
\text { RIK2,GRIK1 }\end{array}$ \\
\hline Glutamate Receptor Signaling & 3.85 & GRM5,GRID2,GRIA1,GNG2,GRIK3,GRIK2,GNG7,GRIK1 \\
\hline Endocannabinoid Developing Neuron Pathway & 3.65 & $\begin{array}{l}\text { FLT3,GNAO1,GNG2,GNAI1,PIK3C2G,FGFR2,PAX6,IRS2, GSK3B,CREB5,CT } \\
\text { NNB1,GNG7 }\end{array}$ \\
\hline Netrin Signaling & 3.4 & CACNA1I,NCK2,CACNG6,UNC5A,CACNB4,RYR3,NFATC1,CACNA1A \\
\hline Calcium Signaling & 2.91 & $\begin{array}{l}\text { CACNA11,CACNG6,MYH10,HDAC4,MYH13,GRIA1,CACNB4,TRPC4,CREB } \\
\text { 5,NFATC1,CACNA1A,RYR3,SLC8A1,GRIK1 }\end{array}$ \\
\hline G Beta Gamma Signaling & 2.77 & $\begin{array}{l}\text { CACNA1I,CACNG6,SHC1,GNAO1,CACNB4,GNG2,GNAI1,PRKCH,GNG7,C } \\
\text { ACNA1A }\end{array}$ \\
\hline Integrin Signaling & 2.6 & $\begin{array}{l}\text { TSPAN5,ITGA8,FLT3,PIK3C2G,TSPAN2,FGFR2,TNK2,ITGAL,NCK2,SHC1,IR } \\
\text { S2,GSK3B,CTTN,NEDD9 }\end{array}$ \\
\hline Axonal Guidance Signaling & 2.42 & $\begin{array}{l}\text { MMP20,LRRC4C,UNC5A,NTN4,GNG2,FLT3,PIK3C2G,GNAI1,SEMA6B,FG } \\
\text { FR2,SLIT2,DPYSL5,PDGFC,GNG7,NFATC1,NCK2,SHC1,SEMA6D,NTNG2,G } \\
\text { NAO1,IRS2,PRKCH,GSK3B,SEMA3C }\end{array}$ \\
\hline Androgen Signaling & 2.37 & $\begin{array}{l}\text { CACNA1I,CACNG6,SHC1,GNAO1,CACNB4,GNG2,GNAI1,PRKCH,GNG7,C } \\
\text { ACNA1A }\end{array}$ \\
\hline Relaxin Signaling & 2.31 & $\begin{array}{l}\text { PDE10A,RXFP1,FLT3,GNAO1,GNG2,GNAI1,PIK3C2G,FGFR2,IRS2,PDE4B, } \\
\text { GNG7 }\end{array}$ \\
\hline Growth Hormone Signaling & 2.02 & FLT3,CSHL1,PIK3C2G,FGFR2,CSH1/CSH2,IRS2,PRKCH \\
\hline Gap Junction Signaling & 1.95 & $\begin{array}{l}\text { GJA10,GRIA1,FLT3,GRIK3,GNAI1,PIK3C2G,FGFR2,IRS2,PRKCH,GRIK2,CT } \\
\text { NNB1,GRIK1 }\end{array}$ \\
\hline Synaptic Long Term Depression & 1.94 & $\begin{array}{l}\text { GRM5,CACNA1I,CACNG6,GRIA1,GRID2,RYR3,GNAO1,CACNB4,GNAI1,P } \\
\text { RKCH,CACNA1A }\end{array}$ \\
\hline G-Protein Coupled Receptor Signaling & 1.94 & $\begin{array}{l}\text { HTR5A,PDE10A,FLT3,PIK3C2G,GNAI1,FGFR2,DRD5,PDE4B,CREB5,CHRM } \\
\text { 3,GRM5,SHC1,GNAO1,IRS2,DUSP4 }\end{array}$ \\
\hline GABA Receptor Signaling & 1.82 & CACNA1I,CACNG6,KCNN3,GABRB3,CACNB4,SLC6A1,CACNA1A \\
\hline Huntington's Disease Signaling & 1.68 & $\begin{array}{l}\text { GRM5,SHC1,HDAC4,IFT57,FLT3,GNG2,PIK3C2G,FGFR2,DNM3,IRS2,PRKC } \\
\text { H,CREB5,GNG7 }\end{array}$ \\
\hline Neurotrophin/TRK Signaling & 1.55 & SHC1,FLT3,PIK3C2G,FGFR2,IRS2,CREB5 \\
\hline$\alpha$-Adrenergic Signaling & 1.42 & GNG2,GNAI1,PRKCH,PYGL,SLC8A1,GNG7 \\
\hline Canonical Pathways (Validation) & -log(p-value $)^{*}$ & Molecules \\
\hline CREB Signaling in Neurons & 4.15 & $\begin{array}{l}\text { RAP2B,CACNG6,CACNA1H,PIK3R5,GNAI1,GNG7,GRM5,ADCY9,CACNA2 } \\
\text { D1,ADCY1,PRKAR1B,PIK3R6,ATF4,IRS2,CACNB2,ADCY8,GNAL,GRIA3 }\end{array}$ \\
\hline Endocannabinoid Developing Neuron Pathway & 4.02 & $\begin{array}{l}\text { RAP2B,PIK3R5,GNAI1,GNG7,ADCY9,ADCY1,PRKAR1B,PIK3R6,ATF4,IRS2, } \\
\text { ADCY8,CTNNB1,GNAL }\end{array}$ \\
\hline Calcium Signaling & 3.14 & $\begin{array}{l}\text { RAP2B,CACNG6,HDAC4,MYH9,MYH14,HDAC1,CACNA1H,TRPC7,CACNA } \\
\text { 2D1,MYH3,PRKAR1B,ATF4,CACNB2,CHRNA3,GRIA3 }\end{array}$ \\
\hline GABA Receptor Signaling & 2.77 & $\begin{array}{l}\text { GABRG3,CACNG6,ADCY9,ADCY1,CACNA2D1,GABRA6,CACNA1H,CACN } \\
\text { B2,ADCY8 }\end{array}$ \\
\hline G Beta Gamma Signaling & 2.6 & $\begin{array}{l}\text { RAP2B,CACNG6,ADCY1,CACNA2D1,GNAI1,PRKAR1B,CACNA1H,CACNB2 } \\
\text {,GNG7,GNAL }\end{array}$ \\
\hline Gap Junction Signaling & 2.56 & $\begin{array}{l}\text { RAP2B,GJA1,ACTB,PIK3R5,GNAI1,ADCY9,ADRB1,ADCY1,PRKAR1B,PIK3R } \\
\text { 6,IRS2,CTNNB1,ADCY8,GRIA3 }\end{array}$ \\
\hline Synaptic Long Term Depression & 2.18 & $\begin{array}{l}\text { RAP2B,GRM5,CACNG6,CACNA2D1,GNAI1,CACNA1H,CACNB2,PPP2R5C, } \\
\text { PPP2R5E,NOS2,GNAL,GRIA3 }\end{array}$ \\
\hline Netrin Signaling & 1.94 & CACNG6,CACNA2D1,PRKAR1B,CACNA1H,CACNB2,UNC5C \\
\hline Notch Signaling & 1.66 & MAML2,HES7,JAG1,PSEN1 \\
\hline Ephrin Receptor Signaling & 1.48 & ITGB1,RAP2B,EPHA6,SDCBP,SH2D3C,GNAI1,ATF4,EPHA3,GNG7,GNAL \\
\hline Serotonin Receptor Signaling & 1.48 & ADCY9,SMOX,ADCY1,ADCY8 \\
\hline Axonal Guidance Signaling & 1.37 & $\begin{array}{l}\text { RAP2B,ITGB1,BMP4,NRP2,ADAMTS20,PTCH1,PIK3R5,GNAI1,EPHA3, RO } \\
\text { BO1,GNG7,EPHA6,SDCBP,WNT3A,PIK3R6,PRKAR1B,IRS2,BMP6,MMP17, } \\
\text { GNAL,UNC5C }\end{array}$ \\
\hline
\end{tabular}


medRxiv preprint doi: https://doi.org/10.1101/2021.02.21.21252162; this version posted February 23, 2021. The copyright holder for this preprint (which was not certified by peer review) is the author/funder, who has granted medRxiv a license to display the preprint in perpetuity.

All rights reserved. No reuse allowed without permission.

Table 3. Nervous system functions enriched among DDE DMR-associated genes from discovery and validation sets

\begin{tabular}{|c|c|c|}
\hline $\begin{array}{l}\text { Nervous system development and functions } \\
\text { (Discovery) }\end{array}$ & p-value* & Molecules \\
\hline Development of central nervous system & $3.71 \mathrm{E}-06$ & $\begin{array}{l}\text { ANKLE2,ASIC2,ATOH1,CNTN6,CNTNAP2,EML1,GRIK1,G } \\
\text { SK3B,HGF,JARID2,MBP,MYO16,PAX6,PDGFC,PROX1,TR } \\
\text { APPC9 }\end{array}$ \\
\hline Synaptic transmission & $1.22 \mathrm{E}-03$ & $\begin{array}{l}\text { ASIC2,GRIA1,GRIK1,GRIK2,GRM5,MBP,NRG3,RIT2,SLC6 } \\
\text { A1,SYT1 }\end{array}$ \\
\hline Recognition of neurons & $2.23 \mathrm{E}-03$ & NTM,OPCML \\
\hline Outgrowth of neurites & $3.11 \mathrm{E}-03$ & GFRA2,GSK3B,HGF,mir-124,SHC1,SLIT2,TGFA \\
\hline Guidance of axons & 3.88E-03 & DOK5,GFRA2,IRS2,NRXN3,NTN4,SHC1,SLIT2,UNC5A \\
\hline Generation of nervous tissue cell lines & 7.17E-03 & MYT1L,RMST \\
\hline Outgrowth of axons & $1.06 \mathrm{E}-02$ & HGF,SLIT2 \\
\hline Formation of brain & 1.83E-02 & CNTNAP2,EML1,GSK3B,HGF,MYO16,TRAPPC9 \\
\hline $\begin{array}{l}\text { Nervous system development and functions } \\
\text { (Validation) }\end{array}$ & p-value* & Molecules \\
\hline Recognition of neurons & $2.50 \mathrm{E}-03$ & NTM,OPCML \\
\hline Outgrowth of neurites & 4.23E-03 & BMP4,ITGA1,ITGB1,mir-10,TGFA,TIAM1,WNT3A \\
\hline Proliferation of neuronal cells & $5.08 \mathrm{E}-03$ & BMP4,ITGA1,ITGB1,JAG1,mir-10,TGFA,TIAM1,WNT3A \\
\hline Neurotransmission & $9.48 \mathrm{E}-03$ & $\begin{array}{l}\text { CBLN1,DTNA,GPR176,GRM5,KCNQ1,MBP,MYH14,PSEN } \\
\text { 1,SYT1 }\end{array}$ \\
\hline Quantity of neuroepithelial cells & $1.18 \mathrm{E}-02$ & BMP4,BMP6 \\
\hline
\end{tabular}

*Fisher exact $p$-value indicating the probability that the indicated function is not enriched among the indicated genes based on the reference set of genes in the IPA Knowledgebase 
medRxiv preprint doi: https://doi.org/10.1101/2021.02.21.21252162; this version posted February 23, 2021. The copyright holder for this preprint (which was not certified by peer review) is the author/funder, who has granted medRxiv a license to display the preprint in perpetuity.

All rights reserved. No reuse allowed without permission.

Table 4. List of top classifier genes for DDE tertile prediction from a combination of two separate machine learning analyses

\begin{tabular}{|c|c|c|c|c|c|c|}
\hline Chr & start & end & annotation & $\begin{array}{l}\text { distance } \\
\text { to TSS }\end{array}$ & Gene Symbol & Gene Name \\
\hline chr2 & 98280512 & 98281225 & Intron 23 of 28 & 193396 & VWA3B & $\begin{array}{l}\text { von Willebrand factor A domain } \\
\text { containing } 3 \mathrm{~B}\end{array}$ \\
\hline chr2 & 240961395 & 240961697 & Intron 20 of 31 & 5754 & LOC200772 & uncharacterized LOC200772 \\
\hline chr3 & 17133705 & 17133973 & Distal Intergenic & 123211 & PLCL2 & phospholipase C like 2 \\
\hline chr3 & 43484849 & 43485664 & Intron 11 of 12 & 136404 & ANO10 & anoctamin 10 \\
\hline chr4 & 2161268 & 2161626 & Intron 11 of 23 & 67605 & POLN & DNA polymerase nu \\
\hline chr5 & 7927007 & 7928271 & Distal Intergenic & 30570 & MTRR & $\begin{array}{l}\text { 5-methyltetrahydrofolate- } \\
\text { homocysteine methyltransferase } \\
\text { reductase }\end{array}$ \\
\hline chr9 & 65389175 & 65390088 & Distal Intergenic & -103966 & FOXD4L5 & forkhead box D4 like 5 \\
\hline chr10 & 14980617 & 14981682 & Intron 1 of 2 & 8062 & & ?? \\
\hline $\operatorname{chr} 10$ & 128066899 & 128068111 & Intron 11 of 20 & 159838 & PTPRE & $\begin{array}{l}\text { protein tyrosine phosphatase, } \\
\text { receptor type E }\end{array}$ \\
\hline chr10 & 14989759 & 14992906 & Distal Intergenic & 17204 & & ?? \\
\hline chr13 & 110824201 & 110825915 & Distal Intergenic & -11117 & LINC00567 & $\begin{array}{l}\text { long intergenic non-protein coding } \\
\text { RNA } 567\end{array}$ \\
\hline $\operatorname{chr} 13$ & 114042350 & 114043198 & Intron 3 of 23 & 89413 & RASA3 & RAS p21 protein activator 3 \\
\hline chr20 & 63948311 & 63949065 & Exon 2 of 3 & 7350 & UCKL1 & uridine-cytidine kinase 1 like 1 \\
\hline $\operatorname{chr} 22$ & 46103014 & 46103671 & Exon 4 of 5 & 49145 & MIRLET7BHG & MIRLET7B host gene \\
\hline $\operatorname{chr} 22$ & 46104978 & 46105643 & Exon 5 of 5 & 51109 & MIRLET7BHG & MIRLET7B host gene \\
\hline
\end{tabular}


medRxiv preprint doi: https://doi.org/10.1101/2021.02.21.21252162; this version posted February 23, 2021. The copyright holder for this preprint (which was not certified by peer review) is the author/funder, who has granted medRxiv a license to display the preprint in perpetuity.

All rights reserved. No reuse allowed without permission.

Table 5. Differential methylation of $S N O R D 115-30$ and $S N O R D 115-37$ by DDE tertile validated by pyrosequencing analyses

\begin{tabular}{|c|c|c|c|c|c|c|c|c|}
\hline \multicolumn{8}{|c|}{ SNORD115-30* } & \multirow{2}{*}{$\begin{array}{c}\text { Average } \\
\text { All Positions }\end{array}$} \\
\hline Tertile & Pos. 1 & Pos. 2 & Pos. 3 & Pos. 4 & Pos. 5 & Pos. 6 & Pos. 7 & \\
\hline First & 28.98 & 30.76 & 34.31 & 33.49 & 37.26 & 44.31 & 30.56 & 34.24 \\
\hline Third & 33.82 & 35.65 & 39.14 & 37.78 & 39.80 & 47.28 & 33.46 & 38.13 \\
\hline $\begin{array}{l}\text { Difference } \\
\text { (Third-First) }\end{array}$ & 4.84 & 4.89 & 4.82 & 4.30 & 2.54 & 2.97 & 2.89 & 3.89 \\
\hline
\end{tabular}

*Methylation was quantified at 7 specific positions in the SNORD115-30 DMR

\begin{tabular}{|l|c|c|c|c|c|}
\hline \multicolumn{7}{|c|}{ SNORD115-37 } & Average \\
\hline Tertile & Pos. 1 & Pos. 2 & Pos. 3 & Pos. 4 & All positions \\
\hline First & 41.12 & 36.29 & 33.84 & 41.63 & 38.22 \\
\hline Third & 45.86 & 41.88 & 39.41 & 46.01 & 43.29 \\
\hline Difference & & & & & \\
(Third-First) & 4.74 & 5.59 & 5.57 & 4.38 & 5.07 \\
\hline
\end{tabular}


Table 6. Significant overlap among DMR-associated genes from different ASD studies and tissues compared to the DDE DMR-associated genes from this study

\begin{tabular}{|c|c|c|c|}
\hline \multirow{2}{*}{\multicolumn{2}{|c|}{$\begin{array}{l}\text { Samples for comparison of DDE DMRs (sperm) } \\
\text { (\# DMR-associated genes) }\end{array}$}} & \multicolumn{2}{|c|}{ Hypergeometric distribution Q-value } \\
\hline & & \multirow{2}{*}{$\frac{\text { Discovery } \quad(742)}{2.96 \mathrm{E}-23}$} & \multirow{2}{*}{$\frac{\text { Validation }(763)}{8.56 \mathrm{E}-10}$} \\
\hline Cord blood from newborns later diagnosed with ASD $^{1}$ & $(2173)$ & & \\
\hline Sperm (high ASD risk) ${ }^{2}$ & $(144)$ & $1.22 \mathrm{E}-06$ & $9.95 \mathrm{E}-05$ \\
\hline Placenta (ASD outcome) $)^{3}$ & $(596)$ & $1.56 \mathrm{E}-04$ & $6.78 \mathrm{E}-05$ \\
\hline Brain (Dup15q) & $(942)$ & $1.90 \mathrm{E}-03$ & $2.00 \mathrm{E}-03$ \\
\hline Lymphoblastoid cell lines ${ }^{5}$ & $(827)^{*}$ & $1.90 \mathrm{E}-02$ & 8.00E-02 \\
\hline Pan-Cancer ${ }^{6}$ & $(434)^{\bullet}$ & $7.34 \mathrm{E}-12$ & 2.17E-09 \\
\hline Faroese cord blood (DDE associated) ${ }^{7}$ & $(1136)$ & 0.608 & 0.55 \\
\hline \multicolumn{4}{|l|}{${ }^{1}$ Mordaunt et al., 2020} \\
\hline \multicolumn{4}{|l|}{${ }^{2}$ Feinberg et al., 2015} \\
\hline \multicolumn{4}{|l|}{${ }^{3}$ Zhu et al., 2019} \\
\hline \multicolumn{4}{|l|}{${ }^{4}$ Dunaway et al., 2016} \\
\hline \multicolumn{4}{|l|}{${ }^{5}$ Hu et al., 2020; *males only, severely language-impaired } \\
\hline \multicolumn{4}{|l|}{${ }^{6}$ Su et al., 2018; "hypermethylated canyon genes } \\
\hline \multicolumn{4}{|l|}{${ }^{7}$ Leung et al., 2018} \\
\hline Note: Ref \#s will be revised after final list of refs is gen & rated & & \\
\hline
\end{tabular}

Note: the superscript ref \#s will be changed to whatever ref \# applies to the respective study in this manuscript. 
medRxiv preprint doi: https://doi.org/10.1101/2021.02.21.21252162; this version posted February 23, 2021. The copyright holder for this preprint (which was not certified by peer review) is the author/funder, who has granted medRxiv a license to display the preprint in perpetuity.

All rights reserved. No reuse allowed without permission.

Table 7. Canonical pathways enriched among overlapping DDE DMR-associated genes between Faroese sperm and cord tissue

\begin{tabular}{|l|c|l|}
\hline Canonical Pathways & -log(p-value) & Molecules \\
\hline Netrin Signaling & 3.53 & CACNA1I,NCK2,UNC5A \\
\hline GABA Receptor Signaling & 3.06 & CACNA1I,GABRB3,KCNN3 \\
\hline Circadian Rhythm Signaling & 2.71 & CREB5,VIP \\
\hline CREB Signaling in Neurons & 2.02 & CACNA1I,CREB5,GRIK2 \\
\hline Axonal Guidance Signaling & 1.82 & NCK2,NTN4,NTNG2,UNC5A \\
\hline Cellular Effects of Sildenafil (Viagra) & 1.58 & KCNN3,PDE4B \\
\hline GP6 Signaling Pathway & 1.55 & COL25A1,FGA \\
\hline Corticotropin Releasing Hormone Signaling & 1.51 & CACNA1I,CREB5 \\
\hline Extrinsic Prothrombin Activation Pathway & 1.5 & FGA \\
\hline Gustation Pathway & 1.44 & CACNA1I,PDE4B \\
\hline Methionine Degradation I (to Homocysteine) & 1.41 & MGMT \\
\hline Protein Kinase A Signaling & 1.39 & CREB5,PDE4B,PTPRS \\
\hline Cysteine Biosynthesis III (mammalia) & 1.37 & MGMT \\
\hline GNRH Signaling & 1.35 & CACNA1I,CREB5 \\
\hline Ephrin Receptor Signaling & 1.31 & CREB5,NCK2 \\
\hline
\end{tabular}

*Negative logarithm of the Fisher exact $\mathrm{p}$-value indicating the probability that the indicated pathway is not enriched among the indicated genes based on the reference set of genes in the IPA Knowledgebase 


\section{Figure legends}

Figure 1. Overview of workflow for this study

Figure 2. Heatmaps and Manhattan plots depicting the results of the WGBS analyses on the discovery set $(A, C)$ and the validation set $(B, D)$

Figure 3. SNORD115 region showing genome-wide significance for differential methylation between DDE exposure groups after correction for multiple testing

Figure 4. Bar plot of discovery and validation cohort specific $\mathrm{p}$-values from a meta $\mathrm{p}$-value analysis of the least dispensable significant $(p<0.05)$ gene ontology terms from GOfuncR

Figure 5. Venn diagram showing the overlap of DDE DMR-associated genes among the discovery set, the validation set, and SFARI genes

Figure 6. Results of pyrosequencing analyses of DMRs associated with CSMD1 (A, B), RBFOX1 (C), and NRXN2 (D). The box plot (A) shows differential methylation at a single CpG site in $C S M D 1$ while the graphs show the average methylation as a function of DDE serum concentration ( $\mu \mathrm{g} / \mathrm{gm}$ lipid) for CSMD1, RBFOX1 (10 sites, discovery set only), and NRXN2 (7 sites, all samples in both discovery and validation sets). R-squared $\left(\mathrm{r}^{2}\right)$ and $\mathrm{p}$-values for the correlation curves are shown.

Figure 7. Results of pyrosequencing analyses of DMRs associated with MIRLET7BHG. The graph shows the average methylation across $4 \mathrm{CpG}$ sites as a function of DDE serum concentration ( $\mu \mathrm{g} / \mathrm{gm}$ lipid) while the table below shows the methylation differences at each site.

\section{List of Supplemental Materials Supplemental Tables}

Table S1. Summary of demographic and EDC data for sperm donors in each exposure tertile Table S2. DMRs identified in the discovery set Table S3. DMRs identified in the validation set Table S4. DMRs identified in the combined set of 52 samples

\section{Supplemental Figures}

Figure S1. Correlation between serum concentrations of DDE and DDT and between DDE and the sum of 4 PCBs (PCB118, 138, 153, and 180)

Figure S2. Relationship between DDE serum concentrations and BMI and smoking status Figure S3. Correlation between DDE serum concentrations and sperm parameters Figure S4. Annotated genomic sites/regions among DMRs in discovery and validation sets

Supplemental File 1: Primer sequences and PCR conditions for pyrosequencing analyses 
medRxiv preprint doi: https://doi.org/10.1101/2021.02.21.21252162; this version posted February 23, 2021. The copyright holder for this preprint (which was not certified by peer review) is the author/funder, who has granted medRxiv a license to display the preprint in perpetuity.

All rights reserved. No reuse allowed without permission.

Figure 1. Overview of workflow for this study

DNA isolation from sperm

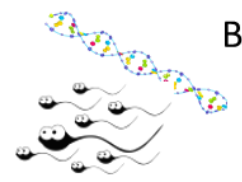

Bisulfite conversion

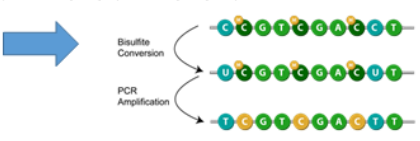

Calculation of percent methylation and identification of differentially methylated regions (DMRs)
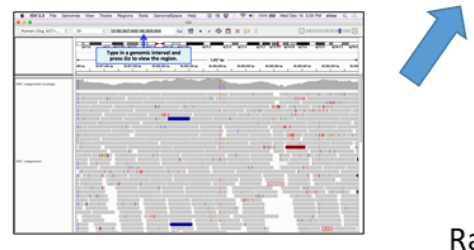

Alignment to reference genome hg38
Raw Data: FASTQ 150bp Paired End
Library prep

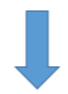

Sequencing

by synthesis

\section{Screen raw data for QC with} FASTQC

Trim and filter for quality with TrimGalore

Repeat FASTQC Screen

Align to reference genome with Bismark

Quantify methylation with Bismark

Differential methylation analysis with Dmrseq

Annotate DMRs

Gene ontology and pathway analyses 
medRxiv preprint doi: https://doi.org/10.1101/2021.02.21.21252162; this version posted February 23, 2021. The copyright holder for this preprint (which was not certified by peer review) is the author/funder, who has granted medRxiv a license to display the preprint in perpetuity.

All rights reserved. No reuse allowed without permission.

Figure 2. Heatmaps and Manhattan plots depicting the results of the WGBS analyses on the discovery set $(A, C)$ and the validation set $(B, D)$

A

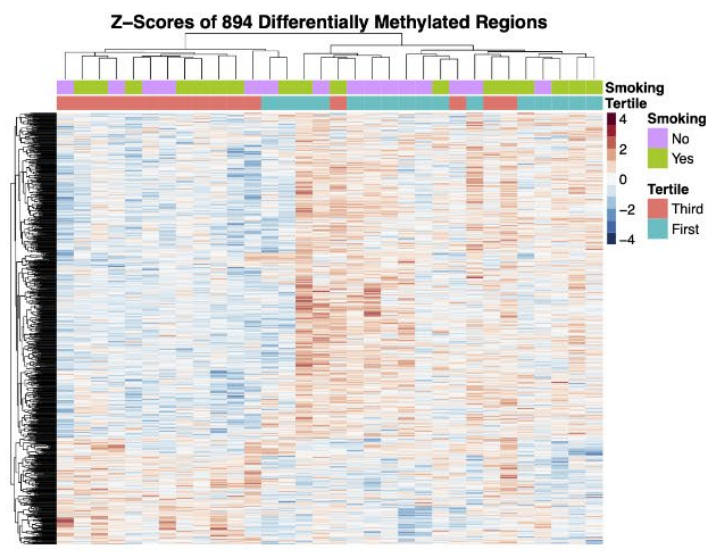

C

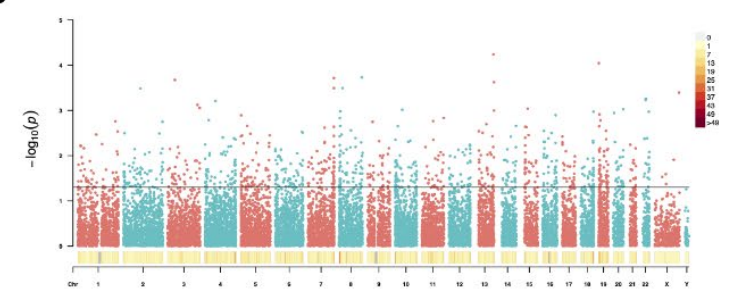

B

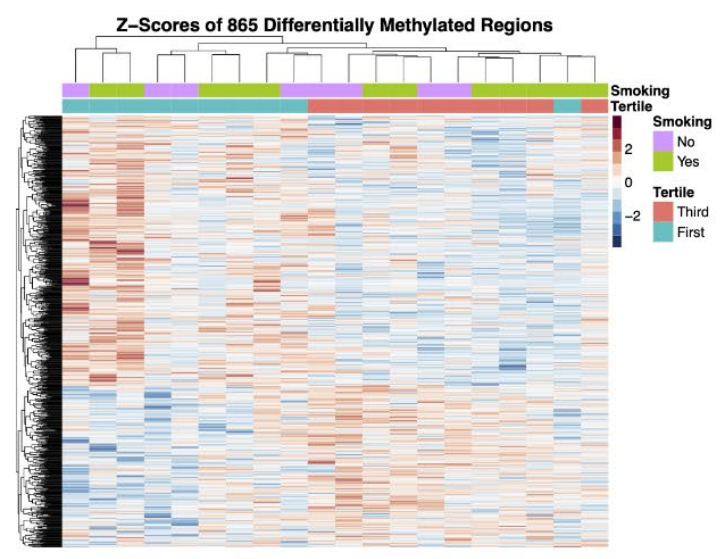

D

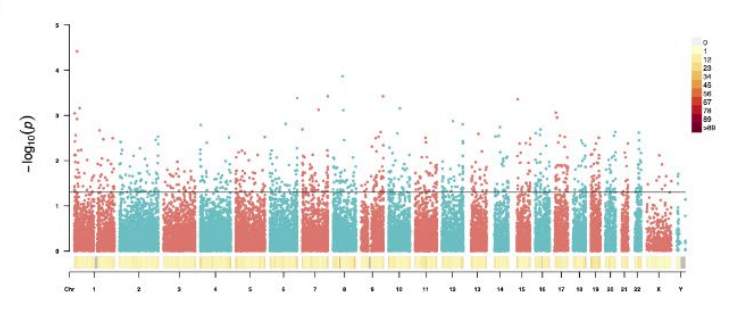


medRxiv preprint doi: https://doi.org/10.1101/2021.02.21.21252162; this version posted February 23, 2021. The copyright holder for this preprint (which was not certified by peer review) is the author/funder, who has granted medRxiv a license to display the preprint in perpetuity.

All rights reserved. No reuse allowed without permission.

Figure 3. SNORD115 region showing genome-wide significance for differential methylation after correction for multiple testing

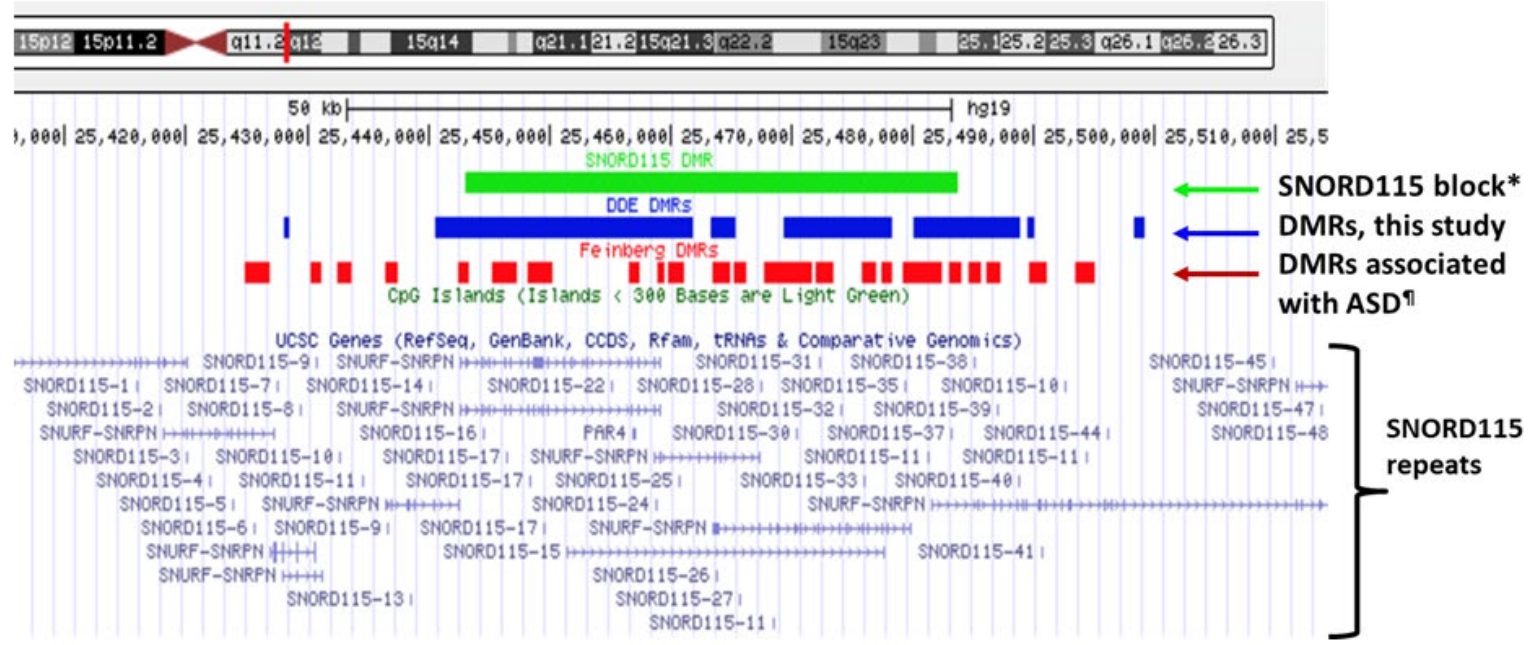


medRxiv preprint doi: https://doi.org/10.1101/2021.02.21.21252162; this version posted February 23, 2021. The copyright holder for this preprint (which was not certified by peer review) is the author/funder, who has granted medRxiv a license to display the preprint in perpetuity.

All rights reserved. No reuse allowed without permission.

Figure 4. Bar plot of discovery and validation cohort specific p-values from a meta $\mathrm{p}$-value analysis of the least dispensable significant $(p<0.05)$ gene ontology terms from GOfuncR

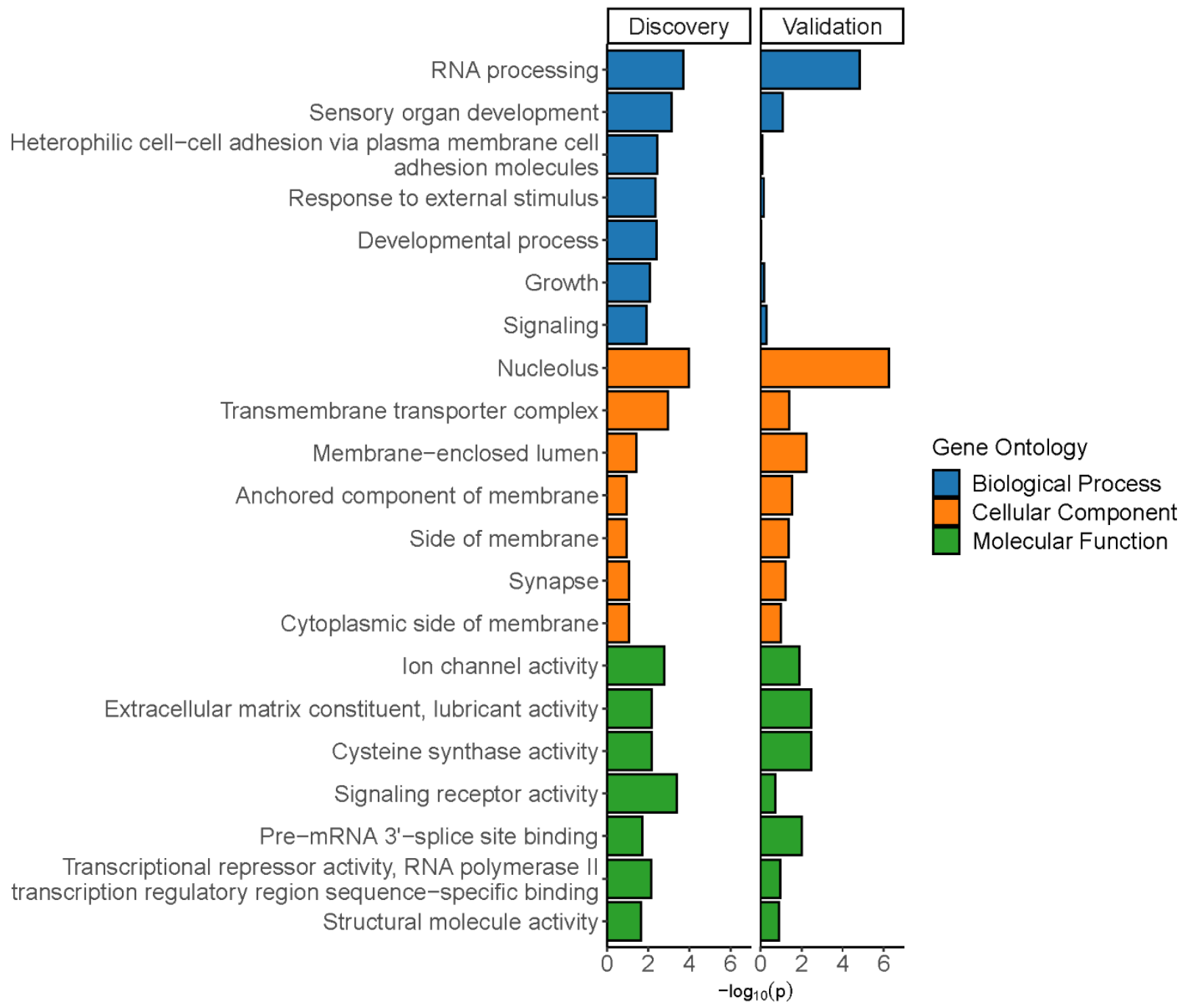


medRxiv preprint doi: https://doi.org/10.1101/2021.02.21.21252162; this version posted February 23, 2021. The copyright holder for this preprint (which was not certified by peer review) is the author/funder, who has granted medRxiv a license to display the preprint in perpetuity.

All rights reserved. No reuse allowed without permission.

Figure 5. Venn diagram showing the overlap of DMR-associated genes among the discovery set, the validation set, and SFARI genes

\begin{tabular}{|l|l|}
\hline CSMD1 & CUB and sushi domain-containing protein 1 \\
\hline HDAC4 & Histone deacetylase 4 \\
\hline RBFOX1 & RNA binding protein fox-1 homolog 1 \\
\hline CHRM3 & Muscarinic acetylcholine receptor M3 \\
\hline JARID2 & Protein Jumonji \\
E \\
\hline KHDRBS2
\end{tabular}


medRxiv preprint doi: https://doi.org/10.1101/2021.02.21.21252162; this version posted February 23, 2021. The copyright holder for this preprint (which was not certified by peer review) is the author/funder, who has granted medRxiv a license to display the preprint in perpetuity.

All rights reserved. No reuse allowed without permission.

Figure 6. Results of pyrosequencing analyses of DMRs associated with CSMD1 (A, B), RBFOX1 (C), and NRXN2 (D). The box plot (A) shows differential methylation at a single CpG site in $C S M D 1$ while the graphs show the average methylation as a function of DDE serum concentration ( $\mu \mathrm{g} / \mathrm{gm}$ lipid) for CSMD1, RBFOX1 (10 sites, discovery set only), and NRXN2 (7 sites, all samples in both discovery and validation sets). R-squared $\left(\mathrm{r}^{2}\right)$ and $\mathrm{p}$-values for the correlation curves are shown.
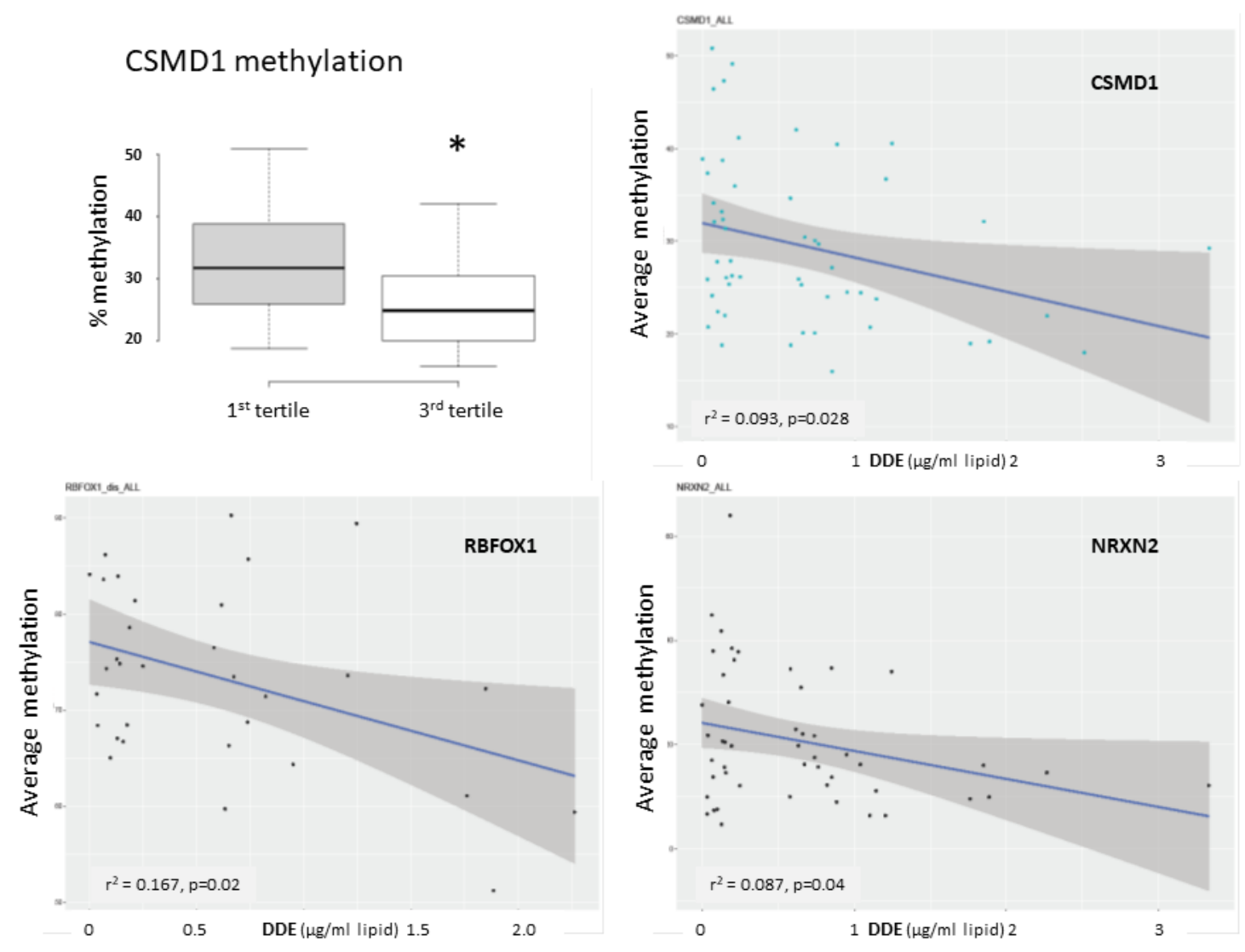
medRxiv preprint doi: https://doi.org/10.1101/2021.02.21.21252162; this version posted February 23, 2021. The copyright holder for this preprint (which was not certified by peer review) is the author/funder, who has granted medRxiv a license to display the preprint in perpetuity.

All rights reserved. No reuse allowed without permission.

Figure 7. Results of pyrosequencing analyses of DMRs associated with MIRLET7BHG. The graph shows the average methylation across $4 \mathrm{CpG}$ sites as a function of DDE serum concentration ( $\mu \mathrm{g} / \mathrm{gm}$ lipid) while the table below shows the methylation differences at each site.

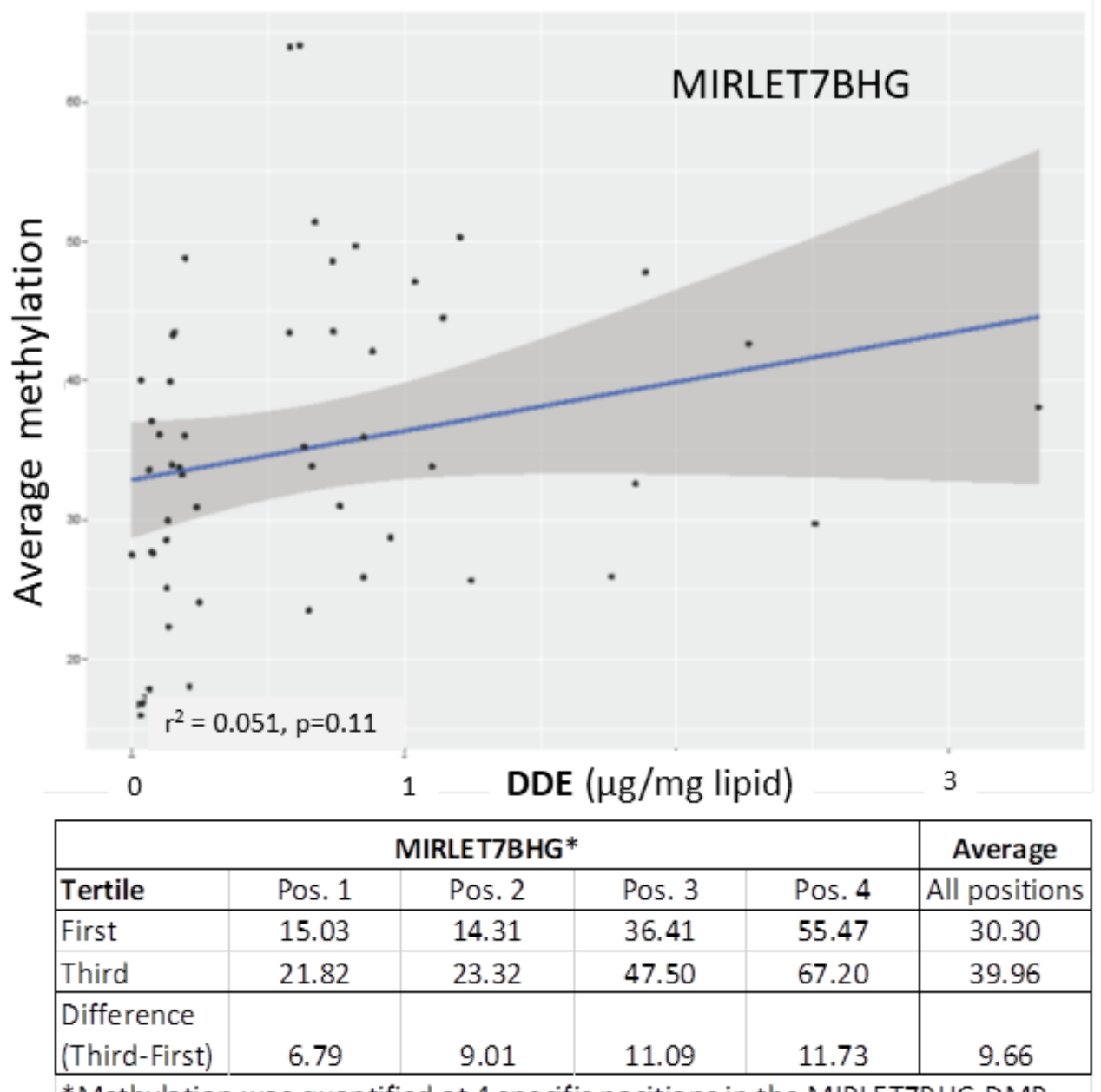

*Methylation was quantified at 4 specific positions in the MIRLET7BHG DMR 